\title{
Deformation as a trigger for pressure sore related muscle damage
}

Citation for published version (APA):

Bosboom, E. M. H. (2001). Deformation as a trigger for pressure sore related muscle damage. [Doctoral Thesis, Maastricht University]. Technische Universiteit. https://doi.org/10.26481/dis.20011012eb

Document status and date:

Published: 01/01/2001

DOI:

10.26481/dis.20011012eb

Document Version:

Publisher's PDF, also known as Version of record

\section{Please check the document version of this publication:}

- A submitted manuscript is the version of the article upon submission and before peer-review. There can be important differences between the submitted version and the official published version of record.

People interested in the research are advised to contact the author for the final version of the publication, or visit the DOI to the publisher's website.

- The final author version and the galley proof are versions of the publication after peer review.

- The final published version features the final layout of the paper including the volume, issue and page numbers.

Link to publication

\footnotetext{
General rights rights.

- You may freely distribute the URL identifying the publication in the public portal. please follow below link for the End User Agreement:

www.umlib.nl/taverne-license

Take down policy

If you believe that this document breaches copyright please contact us at:

repository@maastrichtuniversity.nl

providing details and we will investigate your claim.
}

Copyright and moral rights for the publications made accessible in the public portal are retained by the authors and/or other copyright owners and it is a condition of accessing publications that users recognise and abide by the legal requirements associated with these

- Users may download and print one copy of any publication from the public portal for the purpose of private study or research.

- You may not further distribute the material or use it for any profit-making activity or commercial gain

If the publication is distributed under the terms of Article $25 \mathrm{fa}$ of the Dutch Copyright Act, indicated by the "Taverne" license above, 


\section{Deformation as a trigger for}

pressure sore related muscle damage 
Bosboom, Elisabeth M.H.

Deformation as a trigger for pressure sore related muscle damage / by Elisabeth M.H. Bosboom. - Eindhoven : Technische Universiteit Eindhoven, 2001.

Proefschrift. - ISBN 90-386-2962-1

NUGI 743

Trefwoorden: drukwonden / decubitus / spierschade / spiermechanica Subject headings: pressure ulcers / pressure sores / skeletal muscle damage / skeletal muscle mechanics 


\title{
Deformation as a trigger for pressure sore related muscle damage
}

\author{
PROEFSCHRIFT
}

ter verkrijging van de graad van doctor aan de Universiteit Maastricht, op gezag van de Rector Magnificus, Prof.dr. A.C. Nieuwenhuijzen Kruseman, volgens het besluit van het College van Decanen,

in het openbaar te verdedigen op vrijdag 12 oktober 2001 om 14.00 uur

door

Elisabeth Maria Hendrika Bosboom

geboren te Bunnik op 9 maart 1973 
Promotoren:

Prof.dr. H. Kuipers

Prof.dr.ir. F.P.T. Baaijens (Technische Universiteit Eindhoven)

Copromotoren:

Dr. C.V.C. Bouten (Technische Universiteit Eindhoven)

Dr.ir. C.W.J. Oomens (Technische Universiteit Eindhoven)

Beoordelingscommissie:

Prof.dr. M.J.A.P. Daemen (voorzitter)

Prof.dr. D.L. Bader (Queen Mary, University of London, United Kingdom)

Dr. M.K.C. Hesselink

Prof.dr.ir. J.D. Janssen (Technische Universiteit Eindhoven)

Prof.dr. K. Nicolay (Universiteit Utrecht) 
voor Antonie voor mijn ouders 


\section{Contents}

Summary $\quad$ ix

1 Introduction 1

1.1 Problem definition: Pressure sores . . . . . . . . . . . . . . . 2

1.2 Research on pressure sore aetiology . . . . . . . . . . . . . . . . 4

1.3 Hypotheses on the aetiology of pressure sores . . . . . . . . . 6

$1.4 \mathrm{\Lambda im}$ and outline . . . . . . . . . . . . . . . . 7

2 Quantification and localisation of damage in rat muscles after transverse loading 9

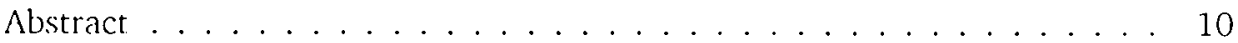

2.1 Introduction . . . . . . . . . . . . . . . . . . . . . . . . . . . . . . . . .

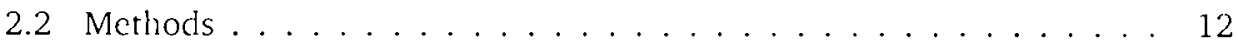

2.2 .1 Ioading procedure .................... 12

2.2.2 Histology and morphologic analysis . . . . . . . . . . 14

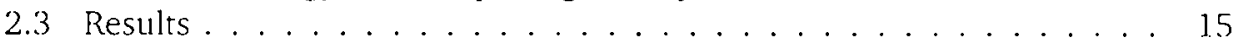

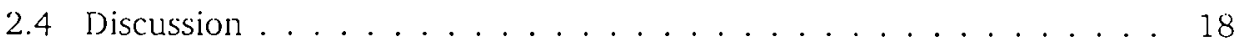

3 High-resolution MRI to assess skeletal muscle damage after transverse loading 21

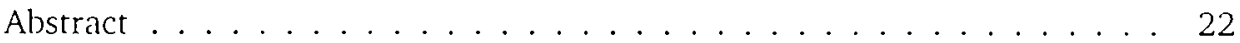

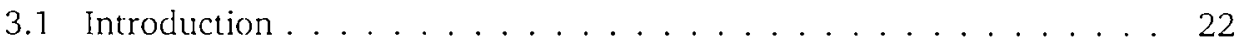

3.2 Methods . . . . . . . . . . . . . . . . . . . 24

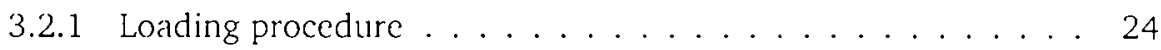

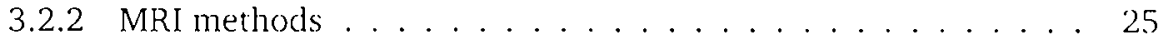

3.2 .3 Histological analysis ................... 25

3.2.4 Comparison MRI and histology ............. 26

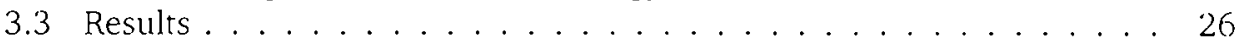

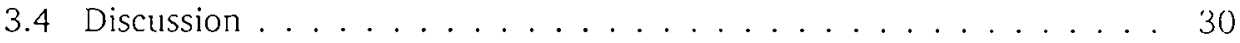

4 Passive transverse mechanical properties of skeletal muscle 33

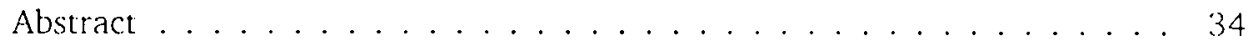

4.1 Introduction . . . . . . . . . . . . . . . . 34

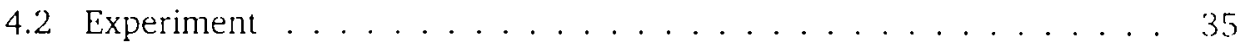


4.2 .1 Preparation . . . . . . . . . . . . . . 35

4.2 .2 Protocol . . . . . . . . . . . . . . . . . 36

4.3 Finite element model and parameter estimation . . . . . . . . . 36

4.4 Results . . . . . . . . . . . . . . . . . . . . . 37

4.5 Discussion . . . . . . . . . . . . . . . . . . . . . . . 39

5 Cell deformation as a trigger for pressure sore related muscle damage 41

Abstract . . . . . . . . . . . . . . . . . . . 42

5.1 Introduction . . . . . . . . . . . . . . . . 42

5.2 Methods ............................ . . . 44

5.2 .1 Animal experiments . . . . . . . . . . . . . . 44

5.2 .2 Finite element model . . . . . . . . . . . . . . . . 45

5.3 Results . . . . . . . . . . . . . . . . . . . . . . . . 47

5.3.1 Animal experiments . . . . . . . . . . . . 47

5.3.2 Finite element model . . . . . . . . . . . . . . . . . . . . . 49

5.4 Discussion . . . . . . . . . . . . . . . . . . . . 51

6 General discussion 53

6.1 Introductory remarks . . . . . . . . . . . . . . . . 54

6.2 Animal model . . . . . . . . . . . . . . . . . . . . . . 54

6.3 Finite element model . . . . . . . . . . . . . . . . . . . . 56

6.4 Deformation as a trigger for pressure sores? . . . . . . . . . . . 57

$\begin{array}{ll}\text { References } & 61\end{array}$

$\begin{array}{ll}\text { Samenvatting } & 67\end{array}$

$\begin{array}{ll}\text { Dankwoord } & 71\end{array}$

$\begin{array}{ll}\text { Curriculum Vitae } & 73\end{array}$ 


\section{Summary}

Pressure sores are localised areas of tissue breakdown in skin and/or underlying tissues such as the subcutaneous fat and muscle. They are primarily caused by prolonged mechanical loading applied at the interface between skin and supporting surfaces and can occur, for example, when patients are bedridden, wheelchair bound or wearing prostheses. Pressure sores are depressing for the patient and can be very painful, especially in the early stages. The prevalence of pressure sores is high; around $10 \%$ of all patients in acute care hospitals have pressure sores. An effective prevention of pressure sores is impeded by a lack of knowledge on the aetiology. It is not known how external loading at skin surface is transferred to local stresses and strains within the tissues and how these local loads eventually can result in tissue damage. Moreover, although prevention focuses on skin, muscle tissue is more susceptible to mechanical loading and the most severe pressure sores often initiate in muscle.

The aim of the present thesis is to obtain insight into the relationship between prolonged mechanical loading and localised muscle damage. A combined approach is chosen involving the development of both an animal model and a finite element model. The animal model aims at relating controlled external loading to the location and amount of muscle damage. The finite element model is developed to assess the local mechanical conditions within the muscle in response to external loading. Comparison of the local muscle damage with the local mechanical conditions within the tissue should then provide information on the local mechanical parameters critical for the onset of damage and enable a better prediction of the consequences of external loading for tissue damage.

Former animal models on the aetiology of pressure sores were limited to the question whether or not damage occurred. Hence, to relate controlled external loading to local muscle damage, a new rat model and damage analysis techniques were employed. The tibialis anterior muscle and overlying skin in the hind limbs of eleven male Brown Norway rats were compressed between an indentor and the tibia for a few hours. The muscle was excised 24 hours after loading and monitored for tissue damage as defined from loss of cross-striation of the muscle fibres and infiltration 
of mononuclear cells. A three dimensional reconstruction of the muscle and the induced damage was obtained and both the amount and the location of damage were quantified using a semi-automated image-processing program. If the loading protocol induced damage, the damage was localised to a zone near the place of indentation, running from superficial to deep muscle layers.

The above-mentioned histological damage analysis techniques have the disadvantage of being labour-intensive and thus limit the number of experiments. Moreover, histological techniques are destructive and therefore exclude follow-up and clinical studies. Hence, besides histology, T2-weighted high-resolution magnetic resonance imaging (MRI) was applied to evaluate the muscle tissue. Using the same experimental set-up to induce damage, in vivo MR images of both the loaded and contralateral hind limb were now obtained 24 hours after loading. Subsequently, the tibialis anterior muscles were processed for histological examination, which was applied to evaluate the MRI results. In the MR images signal intensity appeared higher in the loaded regions of the muscle as compared to the unloaded regions. The location of the region with a higher signal intensity coincided with the location of damage assessed from histology. Moreover, the area of higher signal intensity in the MR image was in good agreement with the area of damage assessed from the histology. It was therefore concluded that MRI is a promising alternative for histological techniques in research on pressure sore aetiology.

To determine the local stresses and strains in the muscle during the loading, a finite element model has been developed of the tibialis anterior muscle and the surrounding tissues. The model makes use of constitutive equations to describe the passive behaviour of the muscle. Since no data were available for the passive transverse properties of skeletal muscle, compression experiments were performed to determine these properties. Special care was taken to maintain the viability of the muscle tissue during the experiments by preserving the neurovascular supply. The protocol led to an inhomogeneous stress- and strain-distribution in the muscle. To assess these a plane stress model was employed, in which an incompressible viscoelastic Ogden model was used to describe the passive muscle behaviour. The material parameters were determined from fitting the modelling results on the experimental data (numericalexperimental method).

However, some modelling uncertainties remained, i.e. the isotropy in the material law for the passive muscle, the transverse properties for skin, the direction of load application and the boundary condition at the membrana interossea, a stiff collagenous membrane between tibia and fibula. To determine the effect of the choices made for these model parameters, extra simulations were performed. From these parameter variations, it was concluded that the majority of the abovementioned choices hardly affected the results $(<8 \%)$. However, changing the 
boundary condition at the interface between muscle and membrana interossea had a major effect. In future studies, the deformation at this boundary should thus be determined, e.g. by applying MRI-tagging.

By comparison between the animal model and the finite element model, the hypothesis was investigated that the onset of pressure sore related muscle damage is triggered by prolonged cell deformation. If a direct relationship exists between cell deformation and muscle damage, the maximum shear strain distributions in the tissue determined by the finite element model must coincide with the amount and location of initial muscle damage assessed in the animal experiments. Although the calculated shear strain distributions showed some overlap with the area of muscle damage, the current results were not convincing enough to conclude that cell deformation is the major trigger for muscle damage. Further research should elucidate the relative role of cell deformation and other causal factors for tissue breakdown (i.e. ischaemia, interstitial changes) in the onset of pressure sore related muscle damage.

The comparison between the animal experiments and the finite element calculations was complicated by the large variation in susceptibility for muscle damage found for the different rats. In clinical observations, differences in susceptibility of patients are explained from different underlying pathologies or differences in additional risk factors, like age, mobility and nutritional state. However, these rationales cannot be applied here as animal characteristics, experimental and loading conditions were strictly controlled. This finding needs further study as the amount of tested animals was limited and only one loading protocol was applied. However, if differences in susceptibility cannot be explained by underlying pathologies or known risk factors, this may have large consequences for pressure sores prevention.

The present thesis demonstrated that deformation can result in considerable muscle damage, but the underlying pathways leading to muscle breakdown still remained unclear. The combined approach, involving both experimental and numerical studies, is however a solid means of obtaining a clear understanding of the aetiology of pressure sores. 
xii Summary 
Chapter 1

\section{Introduction}




\subsection{Problem definition: Pressure sores}

Pressure sores are localised areas of tissue degeneration ranging from redness of the skin to subcutaneous tissue necrosis extending into fat and muscle tissue. They are primarily caused by prolonged mechanical loading at the interface between skin and supporting surfaces. The sores are more commonly referred to as decubitus ulcers or bed sores. These names, however, are misleading as pressure sores not only occur in bedridden patients, but in all situations where prolonged loads act on soft tissues, such as when sitting in a wheelchair or wearing prostheses. Most pressure sores develop near bony prominences, like the sacrum, ischium, hip, heel and ankle (fig 1.1).

Pressure sores can be painful, especially in the early stages and are depressing for the patient. Treatment of pressure sores is difficult and may considerably prolong the duration of hospitalisation. The prevalence of pressure sores is high, around 10\% of all patients in acute care hospitals have pressure sores (Barczak et al., 1997; O'Dea, 1999; Thoroddsen, 1999). Elderly people are particularly susceptible: $81 \%$ of the patients with pressure sores are over 70 years (Thoroddsen, 1999). Hence, due to an increase of the ageing population, pressure sore prevalence is almost certain to grow. Currently, the annual costs of pressure sores in the Netherlands are at least one billion guilders, which is more than one percent of the total health care costs (Health Council of the Netherlands, 1999).

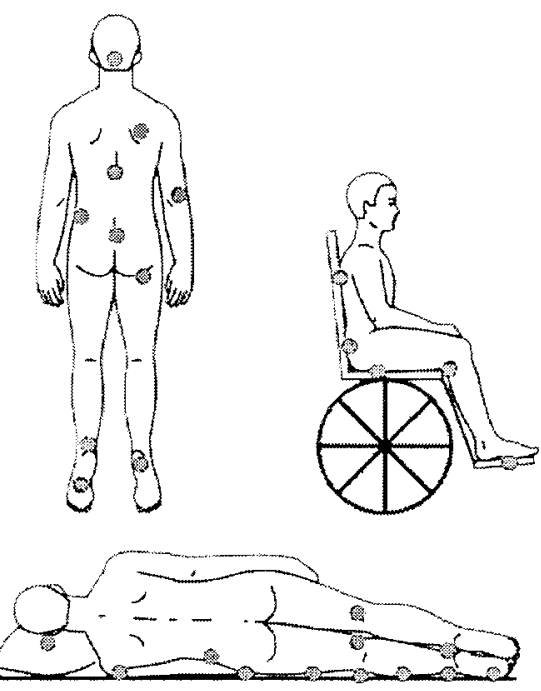

Figure 1.1: Common sites for pressure sores when lying on one's back or side and when sitting in a wheelchair. 
Massive efforts to prevent pressure sores have not resulted in a reduction of the prevalence (Barczak et al., 1997). This is at least partly due to a lack of understanding of the aetiology of pressure sores. Since pressure sores are primarily caused by prolonged interface loading, preventive measures mainly aim at reducing these external loads. It is however not known how the global, external loads are transferred to the underlying tissues. Internal stresses and strains in the tissues are related to external loads in a complicated, non-trivial and nonlinear way, since they depend on tissue geometry and material properties. This especially holds near bony prominences, where an evenly distributed external load can result in highly inhomogeneous internal mechanical conditions. Hence, a reduction in local stresses and strains in the deeper tissue layers may be less than one would expect from a large reduction in external loads (Oomens et al., 2001).

Another problem in pressure sore prevention is that current risk assessment techniques, such as visual inspection and risk assessment scales, mainly focus on the skin. Such a focus does not necessarily give insight into the primary onset, as pressure sores can develop either superficially or from sites within the underlying tissues (Bliss, 1993). Current risk assessment techniques underestimate the occurrence of deep sores and hence intervention is often started too late. Even widely used classification schemes focus on skin and ignore the deeper tissues despite their relevance for pressure sore development (table 1.1). It is generally accepted that the location of the onset of pressure sores is influenced by the nature of the external loading. Superficial pressure sores are mainly caused by shear stresses and initiate in the skin with maceration and detachment of the superficial skin layers. Deep pressure sores, on the other hand, are mainly caused by a prolonged compression of the tissue and start to develop near bony prominences. The damage progresses towards the surface and considerable tissue necrosis can thus be present without any visible signs. In addition, deep sores develop at a faster rate than superficial sores, making them even

Table 1.1: Pressure sores classification scheme (Bours et al., 1999).

\begin{tabular}{|c|c|}
\hline Stage I & $\begin{array}{l}\text { Discolouration of intact skin - light finger pressure applied to the } \\
\text { site does not alter the discolouration }\end{array}$ \\
\hline Stage II & $\begin{array}{l}\text { Partial thickness skin loss or damage involving epidermis, and/or } \\
\text { blister or shallow ulcer without undermining of adjacent tissue }\end{array}$ \\
\hline Stage & $\begin{array}{l}\text { Full thickness skin loss involving damage or necrosis of epidermis } \\
\text { and/or dermis not extending to underlying bone, tendon or joint } \\
\text { capsule }\end{array}$ \\
\hline Stag & $\begin{array}{l}\text { Full thickness skin loss involving damage or necrosis of epidermis } \\
\text { and/or dermis extending to underlying bone, tendon or joint }\end{array}$ \\
\hline
\end{tabular}


more harmful (Bliss, 1992). Hence, the most severe pressure sores initiate in muscle tissue and are to date difficult to detect in an early stage.

Finally, prevention of pressure sores is complicated by a large variation in susceptibility between persons. This susceptibility is influenced by several risk factors, such as age, impaired mobility and nutritional status and makes it difficult to provide adequate guidelines for prevention.

\subsection{Research on pressure sore aetiology}

Most research on pressure sores involves diagnosis, treatment and prevalence. This overview, however, is limited to the relevant studies with respect to the causes of pressure sores (pressure sore aetiology). For more extensive overviews one is referred to review articles on pressure sores (Bliss, 1993; Bouten et al., 1999).

As a guide to pressure sore prevention many attempts have been made to determine threshold values for external loads that will result in tissue damage. These values can be derived either by analysing clinical cases (Reswick and Rogers, 1976) or by performing animal experiments (Kosiak, 1961; Dinsdale, 1974; Daniel et al., 1981; Salcido et al., 1994; Kokate et al., 1995; Goldstein and Sanders, 1998; Peirce et al., 2000). In the animal experiments soft tissues are loaded, mostly by compressing the tissues between an indentor and the underlying bone, while the magnitude and the duration of the compressive loads are varied. The onset of pressure sores is generally defined from the occurrence of tissue damage assessed by histological examination of the tissues.

Although animal experiments have the relative advantage over clinical studies of being better defined and more controllable, a large variation exists in the threshold values for tissue damage found in the different studies (fig 1.2). This variation arises from a diversity in laboratory animals, loading methods and regions of load application. A means of overcoming these differences would be to relate the externally applied mechanical loads to internal local stresses and strains, since these local stresses and strains act on the cellular level where damage initiates. The local mechanical state within the tissues is thus more relevant for tissue damage. Despite the large variations in absolute threshold values, the animal studies have lead to valuable insights. One of the main conclusions is that soft tissues are highly susceptible to loading; within two hours tissue damage can occur (Husain, 1953; Kosiak, 1961; Daniel et al., 1981). More importantly, several researchers have found that muscle tissue is more sensitive to mechanical loading than skin (Husain, 1953; Nola and Vistnes, 1980; Daniel et al., 1981). Two hours of loading resulted in extensive muscle damage consisting of a loss of cross-striation, hyalinisation of fibres 


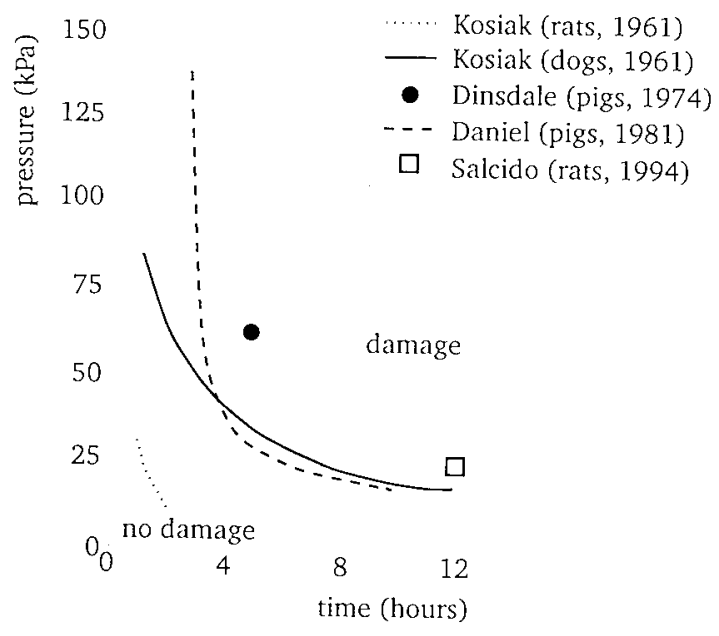

Figure 1.2: Risk curves with regard to pressure sores obtained in different studies. A combination of magnitude and duration of load located above a curve resulted in damage, below the curve no damage was detected.

and infiltration of macrophages (Husain, 1953; Kosiak, 1961; Salcido et al., 1994), while no changes were observed in the skin. In addition, several animal studies demonstrated an inverse relationship between the magnitude and duration of the loading required for tissue damage (fig 1.2), indicating that the lower the load the longer the time needed for tissue damage to occur. In conclusion, skeletal muscle is highly susceptible to external mechanical loading, but to obtain insight in the response of muscle to loading, the local mechanical conditions within the muscle need to be known.

In an attempt to study how the external mechanical loading is transferred to the deeper tissue layers, Dodd and Gross (1991) measured interstitial fluid pressure using wick-in-needle catheters. Such measurements, however, can only be performed on a few selected locations and application to clinical cases leads to ethical problems. Efforts have thus been made to develop physical (Candadai and Reddy, 1992) and numerical models (Chow and Odell, 1978; Dabnichki et al., 1994; Mak et al., 1994; Todd and Thacker, 1994; Oomens et al., 2001) to enable determination of the internal stresses and strains resulting from external loads. Generally, these models are related to wheelchair users and aimed at describing the mechanical state in buttocks supported by cushions. It was found that the highest stresses occurred near the ischial tuberosities and that these stresses were higher than the interface stresses. However, the relationship between interface and internal stresses was not uniform. 
In conclusion, although these numerical models are not yet validated and can be considerably improved, they provide insight into the mechanical conditions within the tissue layers. To date, no numerical modelling has been performed to determine the mechanical conditions within the tissue layers during animal experiments.

\subsection{Hypotheses on the aetiology of pressure sores}

Three basic hypotheses on the aetiology of pressure sores have been commonly postulated. The first and mostly suggested hypothesis focuses on local ischaemia of the soft tissues, following occlusion of capillaries (Kosiak, 1961; Dinsdale, 1974; Daniel et al., 1981). Indeed, capillary perfusion may decrease with increasing mechanical loading (Seiler and Stähelin, 1979; Goossens et al., 1994). However, a threshold value for mechanical loading below which capillary perfusion becomes critical for tissue viability is difficult to provide due to the metabolic activity of the tissues and the autoregulatory mechanisms that restore blood pressure during loading. In addition, there is no experimental evidence relating changes in capillary perfusion to pressure sores. On the contrary, tissues can remain viable without circulation for extended periods of time, e.g. during surgical procedures, whereas pressure sores can develop much faster (Krouskop, 1983). In addition to impaired capillary perfusion, oxygen free radicals mediated during reperfusion following an ischaemic period are suggested as an important damaging factor for pressure sores (Salcido et al., 1994; Peirce et al., 2000). Although reperfusion injury is described for some postischaemic pathologies, like cardiac infarction, the role in the causation of pressure sores still needs to be defined.

The second hypothesis looks at the role of the interstitium between the cells. This theory assumes that mechanical loading results in a disturbance in the metabolic equilibrium around the cells (Krouskop, 1983; Reddy, 1990). It was stated that a change in interstitial pressure, fluid flow and ion concentrations in the interstitium, results in an impaired transport of nutritients and oxygen to the cell, and of waste products from the cell. Failure to restore the metabolic equilibrium eventually results in cell death. This hypothesis is entirely based on theoretical analyses applying phenomenological models; to date there is no experimental evidence relating interstitial changes to cell death.

The third hypothesis states that prolonged deformation of cells plays a major role in the onset of tissue damage (Ryan, 1990; Landsman et al., 1995; Bouten et al., 2001). Cell deformation triggers a variety of effects such as local membrane stresses, volume changes and cytoskeletal reorganisation. Changes in the mechanical and chemical environment of the cell may induce additional damage. In vitro experiments on 
cultured muscle cells, demonstrated that a compressive strain of $10 \%$ and above resulted in a significant increase in cell damage with time compared to unstrained controls (Bouten et al., 1999, 2001). As oxygen and nutrients supply remained constant in these experiments, it was concluded that deformation was the sole trigger for cell damage.

Summarising, the three hypotheses each focus on a different functional unit of the tissue, i.e. the blood capillaries, the interstitial space and the cells. Likely, mechanical loading affects all units. However, the role of each unit in tissue damage is unclear and can depend on the nature of the mechanical loading.

\subsection{Aim and outline}

From the previous, it is clear that pressure sore prevention is impeded by a lack of knowledge on the aetiology of pressure sores. It is not known how external loads are transferred to local stresses and strains within the tissues and how these local loads eventually lead to tissue damage. Moreover, muscle tissue is more sensitive to mechanical loading and the most severe pressure sores often initiate in muscle, whereas prevention is focused on skin. The aim of the present thesis is to obtain more insight in the relation between prolonged mechanical loading and local muscle damage. The research is started from the hypothesis stating that prolonged cell deformation is an important trigger for muscle damage.

In this thesis a combined approach is chosen involving both animal experiments and finite element modelling (fig 1.3). Animal experiments are performed to relate external mechanical loading to the location and amount of muscle damage. The main benefit of our animal experiments over previous experiments is that in our

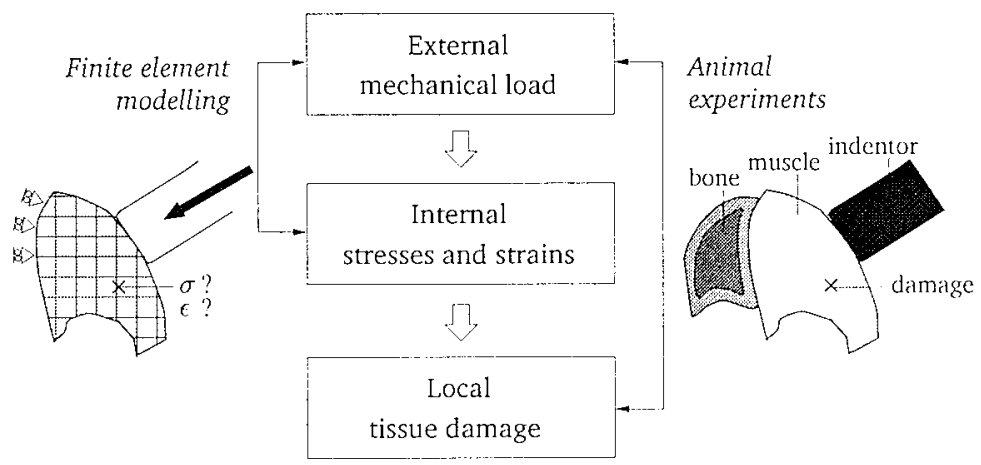

Figure 1.3: Research approach. 
experiments the amount and location of muscle damage are assessed, whereas former research was limited to the question whether or not damage occurred. The finite element model is developed to assess the local stresses and strains within the muscle in response to the external loading during the experiments. Comparison of the location of muscle damage with the local mechanical conditions within the tissue may then provide information on local mechanical parameters critical for the onset of tissue damage. In this way, a better prediction of the consequences of external loading for tissue damage is possible.

Chapter 2 describes the development of the animal model that is used to relate transverse external loading to muscle damage, as well as the histological techniques that are applied to quantify and localise the provoked damage. Histological techniques are precise, but have the disadvantage of being labour-intensive, limiting the amount of experiments. Moreover histological techniques are destructive, thus excluding follow-up studies and clinical applications. Magnetic resonance imaging (MRI) is an alternative which lacks these drawbacks. Hence, in chapter 3 the possibility of high resolution MRI for assessing local muscle damage is described, while histological techniques are used to evaluate the MRI results. A finite element model requires input for the material behaviour. In literature, no data were available on the transverse behaviour of muscle tissue. Chapter 4 thus describes in vivo compression experiments aimed to determine the passive transverse mechanical properties of skeletal muscle. The obtained material properties are applied in the finite element model described in chapter 5. In addition in this chapter, a comparison is made between the results of finite element simulations and the location of muscle damage. This thesis ends with a general discussion of the major findings and directions for future research. 


\section{Chapter 2}

\section{Quantification and localisation of damage in rat muscles after transverse loading}

E.M.H. Bosboom, C.V.C. Bouten, C.W.J. Oomens, H. van Straaten, F.PT. Baaijens, H. Kuipers Quantification and localisation of damage in rat muscles after controlled loading; a new approach to study the aetiology of pressure sores, Medical Engineering and Physics 23:195-200, 2001. 


\section{Abstract}

To obtain more insight in the aetiology of deep pressure sores, an animal model was developed to relate controlled external loading to local muscle damage. The tibialis anterior muscle (TA) and overlying skin of a rat were compressed between indentor and tibia. Loads of 10, 70 and $250 \mathrm{kPa}$ at skin surface were applied for 2 or 6 hours. During half of the 10 and $250 \mathrm{kPa}$ experiments interstitial fluid pressure (IFP) in the TA was measured. The TAs were excised 24 hours after load application. Both amount and location of damage were assessed by histological examination using a semiautomated image-processing program. In six of eleven loaded muscles damage was found. The damage was located from superficial to deep muscle tissue in a zone never exceeding the diameter of the indentor. The IFP measurements interfered with the occurrence of damage; application of 10 and $70 \mathrm{kPa}$ loads only caused damage when combined with IFP measurements, whereas IFP measurements increased damage at $250 \mathrm{kPa}$ loads. The results showed that the developed animal model can be used to provoke local damage by applying a controlled load and that the amount and location of damage can be assessed using the newly developed techniques.

\subsection{Introduction}

Pressure sores are localised areas of tissue degeneration in skin and underlying tissues such as the subcutaneous connective tissue and the muscle tissue. The sores are primarily caused by sustained external (i.e. applied to the skin) mechanical loads. However, preventive measures that aim at reducing these loads, are not always successful in avoiding the occurrence of pressure sores. One of the main reasons is that it is not known how external mechanical loads are transferred to local loads, i.e. local stresses and strains, inside the tissues and how these local loads eventually result in tissue damage. Another difficulty in pressure sore prevention, is that muscle tissue is more susceptible to mechanical loading than skin (Nola and Vistnes, 1980; Daniel et al., 1981). Pressure sores thus often start to develop in the deep muscle layers near bony prominences and progress towards the surface (Bliss, 1993). Current risk assessment techniques fail to assess the risk of these so-called deep sores at an early stage, as they mainly focus on skin.

The only way to obtain insight in the relation between mechanical loading and initial tissue damage is by applying animal models. Hence, as a guide to pressure sore prevention, many researchers performed animal experiments to determine threshold values for external loads that will result in tissue damage (Kosiak, 1961; Dinsdale, 1974; Daniel et al., 1981; Kokate et al., 1995; Goldstein and Sanders, 1998). In these experiments skin and muscle tissue are compressed between an indentor and 
bone and the magnitude as well as the duration of the compressive load are varied. Usually the magnitude of the load is defined as the applied load divided by the area of indentation, whereas the onset of pressure sores is defined as the occurrence of tissue damage assessed from histological examination of the tissues. All the studies resulted in inverse relationships between magnitude and duration of the load (fig 2.1), although considerable differences exist between the various relationships. These differences arise from a diversity in laboratory animals, indentation methods, regions of load application, and definitions of initial tissue damage.

A means of overcoming the diversity in animal models and interpreting the differences between the results would be to relate the applied external load to the local loads inside the tissues, whereas these local loads determine the tissue state and hence the occurrence of tissue damage. A comparison of the local loads with the amount and location of tissue damage will then enable a better prediction of the consequences of mechanical loading for the onset of tissue damage. Additional information is therefore needed on the amount and location of tissue damage, while the mentioned studies were limited to determining whether or not damage occurred. Our research approach combines animal experiments, to find the relationship between controlled external loading and local tissue damage, and numerical modelling, providing information about local loads inside the tissue during the experiments.

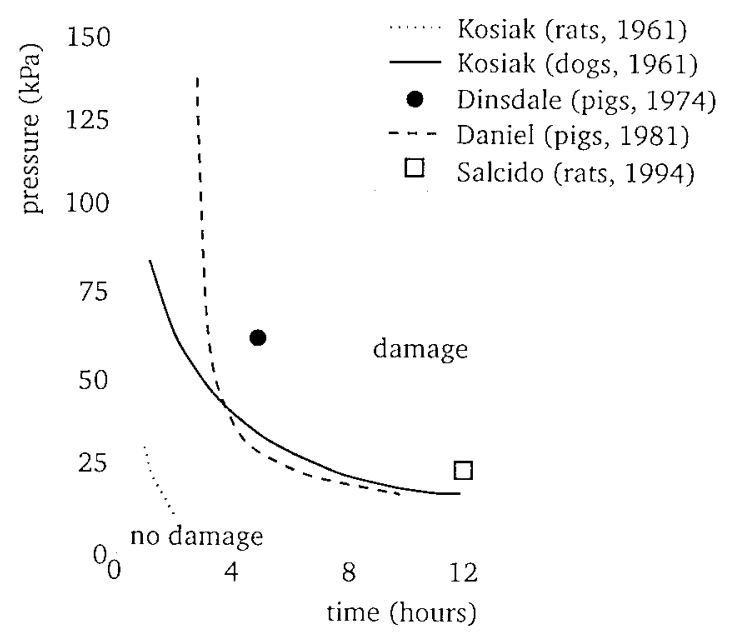

Figure 2.1: Risk curves with regard to pressure sores. A combination of magnitude and duration of load located above a curve resulted in damage, below the curves no damage was detected. 
The aim of the present paper is the development of an animal model that can be used to relate the controlled external loading to local tissue damage and techniques that can be used to quantify and localise the provoked damage. The animal model focuses on muscle tissue, since the most severe deep pressure sores start in muscle. As the reconstruction of the muscle requires a small animal, rats are chosen. Rats have been used as a model for pressure sore formation before (Kosiak, 1961; Salcido et al., 1994; Peirce et al., 2000).

\subsection{Methods}

\subsubsection{Loading procedure}

In total eleven male Brown Norway rats with a weight between 180 and 220 grams were used. The rats were anaesthetised using a combination of ketamine (Nimatek, $0.1 \mathrm{ml} / 100 \mathrm{gram}$ ) and xylazine (Sedamun, $0.05 \mathrm{ml} / 100$ gram) injected subcutaneously. When required, supplemental doses of $0.1 \mathrm{ml}$ ketamine were supplied intraperitoneal. To prevent dehydration these supplemental doses were mixed with saline solution. Body temperature of the rats was kept between $35-37^{\circ} \mathrm{C}$ using a heating pad and heating lamp. In preparation of the loading experiment the hairs on the right tibialis anterior region were cut off, while care was taken not to damage the skin.

The rat was then placed supine in a specially designed loading apparatus, consisting of a unit for fixation of the foot and knee of the right hind limb, and a unit for pressure application (fig 2.2). The foot was fixed on a footplate using adhesive tape and the knee was fixed by clamping the medial and lateral condyles between two concave surfaces. The angles between foot and tibia and between tibia and femur were approximately $90^{\circ}$. The mechanical load was applied using a pneumatically driven indentor with a rounded contact surface $(\varnothing 3.0 \mathrm{~mm})$. The edges of the indentor were curved to avoid high stress concentrations. The loading apparatus allowed positioning of the indentor in all directions. During load application, the indentor was placed halfway between foot and knee perpendicular to the skin overlying the tibialis anterior muscle, at an angle of approximately $40^{\circ}$ with the horizontal. In this way, the tibialis anterior muscle and overlying skin were compressed between the indentor and the tibia (fig 2.3). The location of the indentor relative to the knee, the foot and the tibia, as well as the angle with the horizontal were registered in order to reproduce the loaded area during histological examination.

As the aim of our animal model is to relate controlled external loading to the location and amount of tissue damage, we applied loads that were likely to result in tissue damage, based on values reported in literature. A load of $10 \mathrm{kPa}$ during 2 hours 


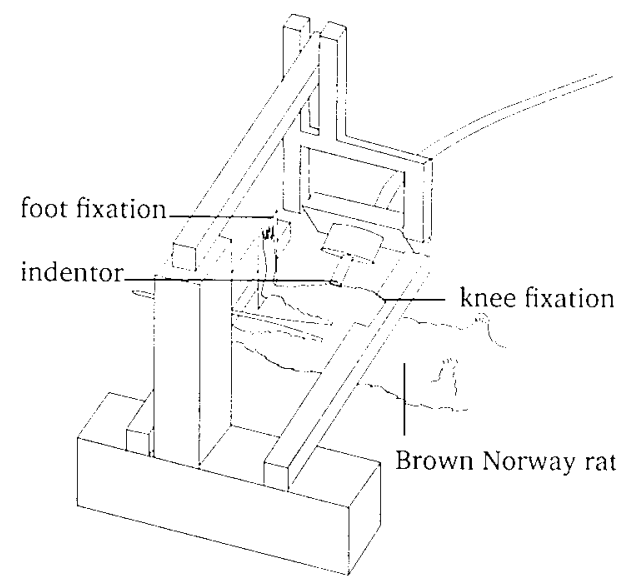

Figure 2.2: Loading apparatus consisting of unit for load application and a unit for fixation of the rat's hind limb.

was comparable to the lowest reported value resulting in muscle damage, i.e. Kosiak (1961) found damage after applying a load of $9.3 \mathrm{kPa}$ during 2 hours. The load of $250 \mathrm{kPa}$ was comparable to the highest reported values (Goldstein and Sanders, 1998). The $70 \mathrm{kPa}$ load was comparable to values reported by Daniel et.al. (Daniel et al., 1981). To examine the effect of longer duration and because of the inverse relationship between magnitude and duration of load (fig 2.1), the lowest load was also applied for 6 hours. Summarising, loads of 10,70 and $250 \mathrm{kPa}$ at the skin surface were applied for 2 hours $(n=3)$ and a load of $10 \mathrm{kPa}$ was applied for 6 hours $(n=2)$. Interstitial fluid pressure (IFP) measurements can be used to study how external loads are transferred to the tissue (Dodd and Gross, 1991). In half of the $10 \mathrm{kPa}$ and $250 \mathrm{kPa}$ experiments (asterisks in table 2.1) IFP was measured using a servo-

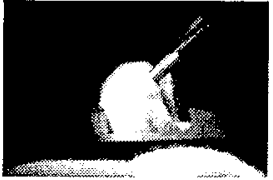

a

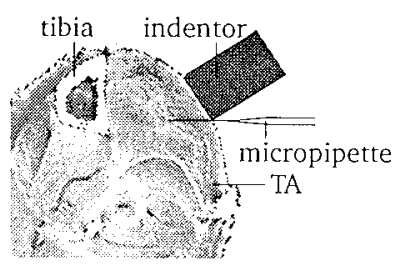

$\mathrm{b}$

Figure 2.3: a. Photograph of the loaded region. b. Cross section of the rat's hind limb during loading showing the compression of the tibialis anterior muscle (TA) between indentor and tibia as well as the position of the micropipette used to measure the IFP. 
controlled counter pressure measurement system (model 5D, IPM Inc.). For this IFP measurement, a glass micropipette containing $2.0 \mathrm{M} \mathrm{NaCl}$ was inserted into the muscle tissue before load application. The micropipette was placed horizontally at a location just beneath the indentor (fig 2.3). A priori, it was assumed that the IFP measurements did not interfere with the occurrence of damage, because the tip diameter of the used micropipettes $(2 \mu \mathrm{m})$ was small compared to the diameter of muscle fibres $(\sim 30 \mu \mathrm{m})$. Moreover, previous research demonstrated that IFP measurements with micropipettes did not lead to inflammatory reactions in muscle and skin (Wiig et al., 1981). Further details on the set-up and results of the IFP measurements are described elsewhere (Bouten et al., 1997).

After the completion of the loading session, the rat was removed from the loading apparatus and observed until it recovered from the anaesthesia. The experimental protocol was approved by the Animal Care Committee of the Maastricht University.

\subsubsection{Histology and morphologic analysis}

Previous research (Husain, 1953; Kosiak, 1961) demonstrated that microscopic tissue damage is clearly visible after twenty-four hours. Therefore, twenty-four hours after completion of the loading session, the right tibialis anterior muscle was excised following perfusion fixation with Bodian's fluid (90\% ethanol 80, 5\% formalin, 5\% glacial acetic acid). For one rat the non-loaded contralateral muscle was excised to serve as control sample, whereas for the other rats the non-loaded areas of the muscle served as controls. The muscle was pinned on a piece of cork to avoid shrinkage and the cork was marked to indicated the position of the loaded area. The muscle was dehydrated in a series of alcohol solutions and embedded in plastic (Technovit 7100 , Kulzer). To obtain a reference system three parallel holes ( $\varnothing 0.5 \mathrm{~mm}$ ) were drilled in the plastic around the muscle. Next, the muscle was cut longitudinally, perpendicular to the direction of load application (section thickness $3 \mu \mathrm{m}$ ). Every 20 th section was saved and mounted on an objective slide. As the diameter of muscle

Table 2.1: Number of experiments performed for each loading regime.

\begin{tabular}{rlc}
\hline & \multicolumn{2}{c}{ duration } \\
\cline { 2 - 3 } applied load & \multicolumn{1}{c}{$2 \mathrm{~h}$} & $6 \mathrm{~h}$ \\
\hline $10 \mathrm{kPa}$ & $\mathrm{n}=3^{*}$ & $\mathrm{n}=2$ \\
$70 \mathrm{kPa}$ & $\mathrm{n}=3$ & \\
$250 \mathrm{kPa}$ & $\mathrm{n}=3^{*}$ & \\
\hline
\end{tabular}

* IFP measured during these loading regimes 
fibres is approximately $30 \mu \mathrm{m}$, in this way every other muscle fibre was preserved. The samples were stained with toluidine blue to visualise both the cross-striated appearance of muscle fibres and the cell nuclei.

The muscle tissue was evaluated using a Leica Quantimet analysis system coupled onto a Leica DMRA automated microscope. Damage was defined as loss of crossstriation of the muscle fibres and/or the infiltration of inflammatory cells. This damage definition was based on previous research on the aetiology of pressure sores (Husain, 1953; Kosiak, 1961; Salcido et al., 1994). The damaged area in a slice was semi-automatically identified and automatically quantified. The repeatability of the assessment of the damaged area per slice was determined by quantifying the damage in the same slice five times. Every other preserved slice was examined completely, so that the area of damage perpendicular to loading was determined every $120 \mu \mathrm{m}$. The slices were recompiled by using the reference system and the volume of damaged tissue was assessed. The location of the damage was determined by linking the reference system to the location of the loaded area, indicated on the cork.

\subsection{Results}

Using the above described experimental techniques damage was found in six of the eleven loaded muscles. None of the control sites showed signs of damage. A distinct difference between damaged and undamaged muscle tissue can be observed (fig 2.4).

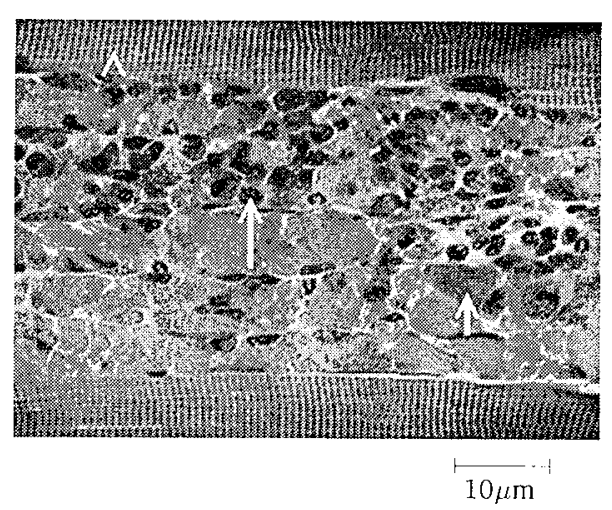

Figure 2.4: Longitudinal section of muscle, $24 \mathrm{~h}$ after loading, showing the typical cross-striated appearance of skeletal muscle (arrowhead), loss of cross-striation of muscle fibres in the damaged area (small arrow) and the infiltration of mononuclear cells (large arrow) (load: $10 \mathrm{kPa}, 2 \mathrm{~h}$. IFP measurement). 
The undamaged tissue has the typical cross-striated appearance of skeletal muscle, while in the damaged tissue the cross-striation has disappeared and mononuclear cells have infiltrated the damaged muscle tissue.

The application of loads of 10 or $70 \mathrm{kPa}$ only caused muscle damage when combined with IFP measurements (table 2.2). At a load of $250 \mathrm{kPa}$ damage was present, but considerably more damage developed when the loading was combined with an IFP measurement. Hence performing the IFP measurement interfered with the occurrence of damage. Considerably more damage resulted from the load of $250 \mathrm{kPa}$ combined with the IFP measurement than from the load of $10 \mathrm{kPa}$ combined with the IFP measurement. During the 6 hours loading regime of $10 \mathrm{kPa}$ muscle damage did not develop.

The identification program that was developed to semi-automatically detect the damaged areas within a slice proved to be effective. The program identified all damaged areas, whereas undamaged areas were not detected (fig 2.5). The assessment of the damaged area per slice was repeatable within $5 \%$.

A three dimensional reconstruction of the damaged tissue is shown in figure 2.6. Damage was located in a zone around a straight line from the indentor to the tibia. This holds for all loading regimes for which damage was found, including those in which IFP measurement were performed. At higher loads, however, the damaged area was broader than at lower loads, but the width never exceeded the diameter of the indentor. Hence the location of damage proved to be reproducible.

Table 2.2: Volume of damaged muscle tissue (in $\mathrm{mm}^{3}$ ).

\begin{tabular}{rcc}
\hline \multirow{2}{*}{ applied load } & \multicolumn{2}{l}{ IFP measurement? } \\
\cline { 2 - 3 } $10 \mathrm{kPa}$ & 0.0 & yes \\
\hline \multirow{2}{*}{$70 \mathrm{kPa}$} & 0.0 & 0.7 \\
& 0.0 & 0.8 \\
\hline & 0.0 & \\
\hline \multirow{2}{*}{$250 \mathrm{kPa}$} & 0.0 & \\
& 3.2 & 14.7 \\
& 4.3 & \\
\hline
\end{tabular}




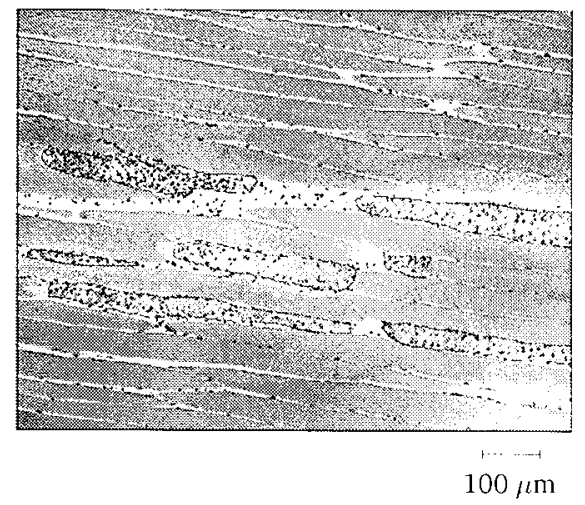

Figure 2.5: Detection of the damaged area within part of a slice (load: $250 \mathrm{kPa}, 2 \mathrm{~h}$. no IFP measurement).

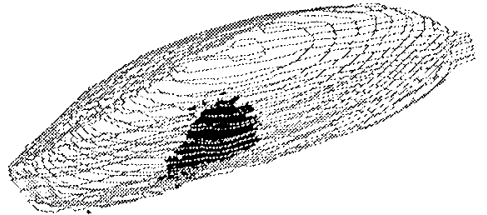

a

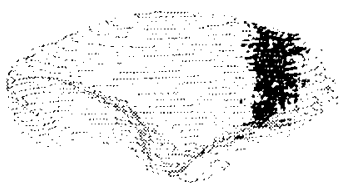

b

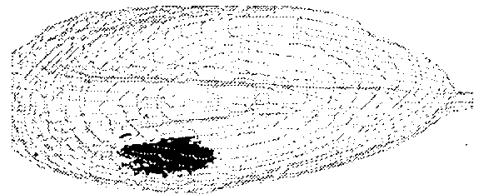

c

Figure 2.6: Three dimensional reconstruction of damaged tissue (load: $250 \mathrm{kPa}, 2 \mathrm{~h}$. no IFP measurement) seen from the lateral side (a), the proximal side (b) and above (c). 


\subsection{Discussion}

Former research on the aetiology of pressure sores using animal models, was limited to the question whether or not damage occurred. Furthermore, in these studies the applied external loads were not related to the local loads within the tissue, whereas these local loads determine the tissue state and thus the occurrence of local tissue damage. To obtain more insight in the effect of mechanical loading on tissue, information is needed on the local mechanical tissue state and the amount and the location of tissue damage.

Therefore, a new rat model has been developed that can be used to relate controlled external loading to local muscle damage. Newly developed techniques enable a semi-automatic quantification and localisation of the provoked damage. Using this approach valuable insights with regard to the location and amount of damage are obtained. In the present experimental set-up damage is located in the zone underneath the indentor and ranges from indentor to bone. Although a priori, such a localised volume of damage was not expected, the location of damage proved to be reproducible. In addition, the developed techniques allow an objective assessment of the amount of damage, repeatable within $5 \%$.

The kind of damage found in these experiments, consisting of a loss of cross-striation and infiltration of macrophages, resembles muscle damage previously described (Husain, 1953; Kosiak, 1961; Salcido et al., 1994). These damage markers are visible 24 hours after the loading of the muscle and are in fact a sign of regeneration of the tissue. Other histological techniques, like immunocytochemical staining or biochemical tests, are being studied to find biological markers able of signalling early cell damage. In addition, the ability of high resolution magnetic resonance imaging to assess local muscle damage is currently under investigation. Magnetic resonance imaging will considerably limit the time needed for the quantification and localisation of damage, and thus enable experiments on a larger scale. Furthermore, magnetic resonance imaging is non-destructive, as opposed to the histological techniques. Hence, studying development of damage in time as well as clinical applications are possible.

IFP measurements were performed to study the transfer of the applied external loads to the muscle tissue, and so to verify the numerical modelling. Previous research demonstrated that IFP measurements with micropipettes did not lead to inflammatory reactions (Wiig et al., 1981), hence no influence of the IFP measurements was expected a priori. However, this conclusion was not based on histological observations. Our experiments demonstrated that IFP measurements with micropipettes did affect the occurrence of damage. The application of loads of $10 \mathrm{kPa}$ or $70 \mathrm{kPa}$ only damaged the muscle tissue when loading was combined 
with IFP measurements. At a load of $250 \mathrm{kPa}$ more damage resulted if the load was combined with the IFP measurement. It is, however, remarkable that damage occurred in areas where the micropipette was not inserted, for example near the tibia, while in some areas where the micropipette was present no damage could be found. It is therefore hypothesised that insertion of a non-flexible micropipette in the muscle tissue made the muscle more vulnerable to loading, possibly by introducing extra volume. Kosiak (1961) also used needles to measure pressure within the tissues while provoking damage. The lower threshold values he found as compared to other investigators (fig 2.1) may as well be explained from the use of these needles. In future research, separate experiments are to be performed when measuring tissue pressure and provoking damage. In addition, special care has to be taken in clinical studies when needles are introduced in the tissues of patients to measure for example subcutaneous interstitial pressures (Bader and White, 1998) or muscle oxygen tension (van der Kleij et al., 1992).

In this research rats were selected, because the reconstruction of the loaded muscle requires a small animal. Rats have been used as a model in older (Husain, 1953; Kosiak, 1961) as well as recent studies (Salcido et al., 1994; Peirce et al., 2000). The soft tissue layers of the rat, in particular the skin, differ from human soft tissue layers (Daniel et al., 1981; Goldstein and Sanders, 1998). This effects the transfer of the mechanical load to the muscle. Therefore, a numerical model will be applied to simulate the experiments and to determine the local stresses and strains within the muscle tissue. Differences in the properties of both skin an subcutaneous fat layer will be accounted for in the numerical model. A comparison of the amount and location of damage, assessed form the experiments, with the local stresses and strains, determined by numerical modelling, will then result in local mechanical criteria that are critical for the onset of damage. This approach will supply detailed insight in the loading of the muscle tissue and the occurrence of damage at a cellular level and lead to a better understanding of the aetiology of deep pressure sores. 
Chapter 2 


\section{Chapter 3}

\section{High-resolution MRI to assess skeletal muscle damage after transverse loading}

E.M.H. Bosboom, C.V.C. Bouten, C.W.J. Oomens, F.P.T. Baaijens, K. Nicolay

High-resolution MRI to assess skeletal muscle damage after prolonged transverse loading, Joumal of Applied Physiology, 2001, submitted. 


\section{Abstract}

To obtain insight in the aetiology of deep pressure sores, understanding is required of the relationship between prolonged transverse loading and local muscle damage. To date, the amount and location of muscle damage were determined by histological examination. In the present study we determined whether T2-weighted highresolution MRI can also be applied to evaluate muscle tissue after prolonged transverse loading. The tibialis anterior muscle and overlying skin in the right hind limbs of five rats were compressed between an indentor and the tibia. The in vivo MR images of the loaded and contralateral hind limbs were obtained 24 hours after load application. The tibialis anterior muscles were then processed for histological examination. In the MR images of all five loaded hind limbs signal intensity appeared higher in the loaded regions of the muscle as compared to the unloaded regions. The location of the higher signal intensity coincided with the location of damage assessed from histology. Also the amount of damage determined with MRI was in good agreement with the amount of damage assessed from histological examination. Because MRI is non-destructive, it is a promising alternative for histology in research on pressure sore aetiology, especially in follow-up studies to evaluate the development of muscle damage in time and in clinical studies.

\subsection{Introduction}

Pressure sores are localised areas of tissue breakdown in skin and/or underlying tissues such as the subcutaneous fat and muscle. They can occur, when people are subjected to prolonged mechanical loads, for example when they are bedridden, wheelchair bound or wearing prostheses. Especially in the early stage, the sores can be very painful and are depressing for the patient. Treatment of pressure sores is difficult and may considerably lengthen the duration of hospitalisation. The prevalence of pressure sores is high, around 10\% of all patients in acute care hospitals have pressure sores (Barczak et al., 1997; O'Dea, 1999; Thoroddsen, 1999). Pressure sores are primarily caused by prolonged loads at the contact area between skin and supporting surfaces. However, preventive measures that aim at reducing the external loads, are not always successful in avoiding the occurrence of pressure sores. One of the main reasons is that there is limited knowledge on how the external mechanical loads lead to breakdown within the tissues. Another complication is that muscle tissue is more susceptible to mechanical loading than skin (Nola and Vistnes, 1980; Daniel et al., 1981). Pressure sores thus often initiate in the deep muscle layers near bony prominences and progress towards the surface (Bliss, 1993). Considerable necrosis can then be present without any visible signs. Current risk assessment techniques, 
such as visual inspection and risk assessment scales, mainly focus on skin and may underestimate the risk of the deep sores.

To obtain insight into the relationship between mechanical loading and tissue damage animal models are employed. In animal experiments, skin and muscle tissue are compressed between an indentor and bone and the magnitude as well as the duration of the compressive load are varied (Kosiak, 1961; Daniel et al., 1981; Salcido et al., 1994; Goldstein and Sanders, 1998; Peirce et al., 2000). The afore-mentioned studies were limited to determining whether or not damage occurred. To enable a better prediction of the consequences of mechanical loading for the onset of tissue damage, additional information is needed on the amount and location of tissue damage. Hence, we developed a rat model to relate controlled external loading to local muscle damage (chapter 2, Bosboom et al., 2001a), as well as damage analysis techniques to quantify and localise the induced muscle damage.

In all previous animal studies histological examination is used for the evaluation. of the tissue. This has two main drawbacks. First, it is labour-intensive, and thus hampers experiments on a larger scale. In addition, histology requires destruction of the tissue and therefore largely excludes clinical studies as well as follow-up studies to investigate the development of tissue damage in time. Magnetic resonance imaging (MRI) is considered a promising alternative, since it is non-destructive and less time consuming. To date, it has not been applied to assess muscle damage related to pressure sores in an early stage. However, MRI has proven to be a valuable tool in the

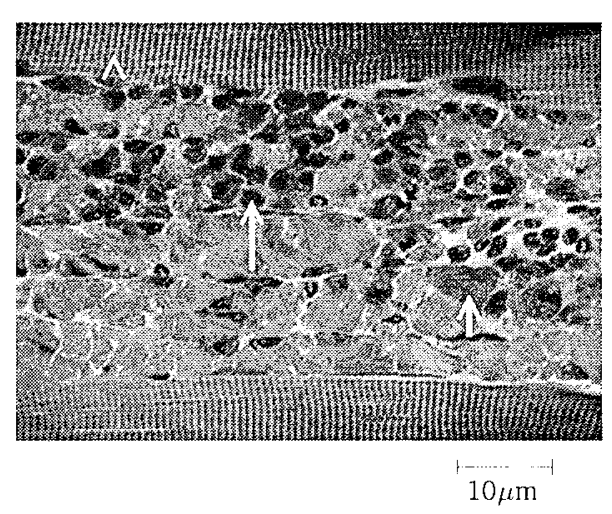

Figure 3.1: Longitudinal section of muscle, $24 \mathrm{~h}$ after loading, showing the typical cross-striated appearance of skeletal muscle (arrowhead), loss of cross-striation of muscle fibres in the damaged area (small arrow) and the infiltration of mononuclear cells (large arrow) (from Bosboom et a1., 2001a). 
planning of therapy for large pressure sores (Hencey et al., 1996) as well as in the evaluation of non-healing pressure sores (Ruan et al., 1998).

In the present study the ability of MRI to assess local muscle damage after prolonged transverse loading is studied. Earlier histological examination revealed that the localised damage in the developed rat model showed complete lysation of muscle fibres (fig 3.1). It is hypothesised that this alteration in the macromolecular makeup of the tissue results in changes of the T2 relaxation time. High-resolution T2-weighted MRI is thus applied to assess the muscle damage and histological examination is used to evaluate the MRI results. The MR images are obtained 24 hours after the loading, as histological examination demonstrated that at this point the lysation of muscle fibres can be clearly observed.

\subsection{Methods}

The animal experiments consisted of three parts. Firstly, the tibialis anterior muscle in the right hind limb of a rat was loaded. This loading procedure took place outside the MRI set-up. Secondly, 24 hours after loading in vivo MR images were obtained of the loaded and contralateral hind limb. Thirdly, following the MRI the tibialis anterior muscles were excised and processed for histological examination. Both the animal model and the histological techniques are presented previously (chapter 2, Bosboom et al., 2001a) and will only be described here in short. The experimental protocol was approved by the Animal Care Committee of the Maastricht University.

\subsubsection{Loading procedure}

Experiments were performed on five male Brown Norway rats weighing 200 230 grams. The rats were anaesthetised using a combination of ketamine (Nimatek, $0.1 \mathrm{ml} / 100$ gram, i.p.) and xylazine (Sedamun, $0.05 \mathrm{ml} / 100 \mathrm{gram}, \mathrm{i.p.}$.) When required, supplemental doses of $0.1 \mathrm{ml}$ ketamine were supplied. Body temperature of the rats was measured with a rectal probe and kept at $35-37^{\circ} \mathrm{C}$ using a heating pad. Prior to the loading hairs on the right tibialis anterior region were cut off, while care was taken not to damage the skin. The rat was then placed supine in a loading apparatus, consisting of a unit for fixation of the tibia of the right hind limb, and a unit for load application. The tibia was fixed by taping the foot on a footplate and by clamping the medial and lateral condyles between two concave surfaces. The angles between foot and tibia and between tibia and femur were approximately $90^{\circ}$. Loading was applied using a pneumatically driven indentor with a rounded contact surface $(\varnothing 3.0 \mathrm{~mm}$ ). The indentor was placed halfway between foot and knee perpendicular to the skin overlying the tibialis anterior muscle, at an angle of approximately $40^{\circ}$ 
with the horizontal. In this way, the tibialis anterior muscle and overlying skin were compressed between the indentor and the tibia during load application. In the present study, a load of $250 \mathrm{kPa}$ at skin surface was applied during 2 hours. After the completion of the loading session, the rat was removed from the loading apparatus, observed until it recovered from the anaesthesia. For the next 24 hours the rat was allowed to move freely and had ad libitum access to food and water.

\subsubsection{MRI methods}

From histological examination it is known that the induced muscle damage is clearly visible 24 hours after loading (Husain, 1953; Kosiak, 1961). The in vivo MRI experiments were therefore performed 24 hours after completion of the loading session. During the MRI experiments, the rat was mechanically ventilated with a mixture of $\mathrm{O}_{2} / \mathrm{N}_{2} \mathrm{O}(1: 2)$ and halothane $(1 \%)$. Body temperature was maintained at $37^{\circ} \mathrm{C}$ using a heating pad.

The rat was placed supine in a 4.7 Tesla Varian 200/400 system, operating at $200 \mathrm{MHz}$. A solenoidal radio frequency coil (inner diameter $16 \mathrm{~mm}, 3$ windings) was placed around the hind limb and the foot was taped to a footplate, so that the knee angle was approximately $180^{\circ}$ and the ankle angle $90^{\circ}$. Longitudinal scout images of the hind limb were made to plan the transverse imaging perpendicular to the proximal aponeurosis of the tibialis anterior muscle. A T2-weighted spin echo sequence was then applied ( $\mathrm{TE}=45 \mathrm{~ms}$, $\mathrm{TR}=5 \mathrm{~s}$ ) to collect 51 consecutive $0.5 \mathrm{~mm}$ thick transverse slices. The images had a field of view of $30 \mathrm{~mm} * 30 \mathrm{~mm}$, a resolution of $256 * 256$ pixels and were the average of 2 acquisitions. Both the loaded and the contralateral hind limb were imaged. The acquisition time was forty-five minutes per hind limb. Immediately following the in vivo MRI, the rat was sacrificed and perfusion fixated with $4 \%$ buffered formalin. Both hind limbs of the rat were excised and stored in formalin.

\subsubsection{Histological analysis}

The loaded tibialis anterior muscle was excised at least a month after the perfusion fixation, to ensure a completed tissue fixation. Next, the muscle was dehydrated in a series of alcohol solutions and embedded in plastic (Technovit 7100, Kulzer). To obtain a reference system three parallel holes $(\varnothing 0.5 \mathrm{~mm})$ were drilled in the plastic around the muscle. Next, the muscle was cut longitudinally, perpendicular to the direction of load application (section thickness $3 \mu \mathrm{m}$ ). Every 50 th section was saved and mounted on an objective slide. The samples were stained with toluidine blue to visualise both the cross-striated appearance of the muscle fibres and the cell nuclei. 
The histological sections were digitised using a Leica DMRA automated microscope. Using an image processing programme in Matlab the contour of the muscle was automatically detected. The damage was indicated manually from evidence of loss of cross-striation of the muscle fibres and/or the infiltration of inflammatory cells. When a muscle fibre was damaged at least every $30 \mu \mathrm{m}$ a mark was placed in the centre of the damaged fibre. In this way, a resolution is obtained of approximately $30 \mu \mathrm{m}$, which is better than the in plane resolution of the MRI $( \pm 120 \mu \mathrm{m})$ and thus suffices for our purposes, i.e. the comparison of histology and MRI. The longitudinal histological sections were recompiled by using the reference system, so that a three dimensional reconstruction of the damaged area in the muscle was obtained.

\subsubsection{Comparison MRI and histology}

A comparison between the $0.5 \mathrm{~mm}$ thick transverse MR images and the $3 \mu \mathrm{m}$ thick longitudinal histological sections cannot be made directly. To enable a comparison, the three dimensional histological reconstruction of the muscle was divided in transverse slices with a thickness of $0.5 \mathrm{~mm}$. A qualitative correspondence in damage location was determined by a visual comparison of the MR image positioned at the middle of the indentor and the corresponding transverse slice from the histological reconstruction.

In addition, the amount of damage assessed from MRI and histology were quantitatively compared by assessing the damaged area in the above described midtransverse images. As the excision and dehydration of the muscle for histology could give rise to a small variation in muscle volume, the damaged area was calculated in percents of the area of the tibialis anterior muscle. In the MR image, first the mean signal intensity and standard deviation of undamaged muscle tissue were determined in an unloaded region. Next, the tibialis anterior muscle was manually traced. Finally, the damaged area in the muscle was assessed by applying a threshold level of the mean signal intensity plus thrice the standard deviation. In the transverse slice of the histological reconstruction the damaged area could be directly calculated. The damaged areas were determined for all loaded muscles and for one control muscle. Finally, linear regression analysis was performed on these six data points to determine the correlation between the MRI and the histology.

\subsection{Results}

In the MR images of all five loaded hind limbs a higher signal intensity was visible in the loaded regions of the tibialis anterior muscle as compared to the unloaded muscles (fig 3.2b). The regions with a higher signal intensity showed a patchy 


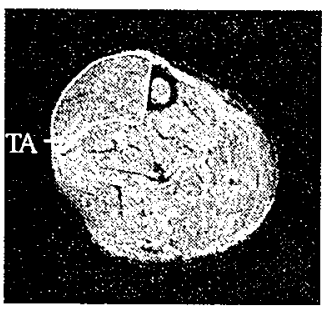

a

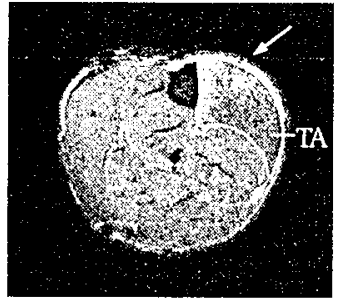

b

Figure 3.2: In vivo MR images of a contralateral, unloaded, left (a) and loaded, right (b) hind limb showing the increase in signal intensity (arrow) in the loaded area ( $T E=45 \mathrm{~ms} ; \mathrm{TR}=5 \mathrm{~s}$ ).

appearance. In the MR images of the contralateral hind limbs no abnormalities in signal intensity were noted (fig 3.2a). Hence, the regions with a higher signal intensity were considered to be damaged. Despite the strictly controlled experimental and loading conditions, there was a large deviation in the amount of damage (fig 3.3), ranging from a highly localised small volume (rat 1) to a more diffuse large volume (rat 5). However, in all rats muscle damage ran from superficial to deep muscle layers.

For one rat (no. 3), next to the regions with high signal intensity, there was also a region with a lower signal intensity as compared to unloaded control tissue. When excising the tibialis anterior muscle of this rat a small hemorrhage was noted, which is known to lead to signal hypointensities in T2-weighted MRI (Blezer et al., 1999). No abnormalities were seen upon excision of the muscles of the other rats. In the MR images of two rats (no. 3 and no. 5), the extensor digitorum longus muscle appeared to be damaged as well. For these two rats, the extensor digitorum muscle was also included in the histological analysis as well as in the comparison between MRI and histology.

Similar to the MRI, the histological examination revealed damage in all five loaded muscles. An example of the three dimensional reconstruction of the histological data is shown in figure 3.4. Further, from histological examination it was found that in some regions only single fibres were affected, while in other regions fibre damage involved all fibres in a zone of more than $1 \mathrm{~mm}$ in crossfibre direction.

Qualitatively, the location of damage in the MR image coincided quite well with the location of damage determined with histological examination (fig 3.3). This holds for all rats, despite the large variations in damage. There were some small differences in the shape of the tibialis anterior muscles between MRI and histology, but these were likely due to the excision of the muscle. 


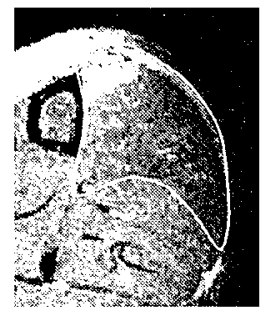

rat 1
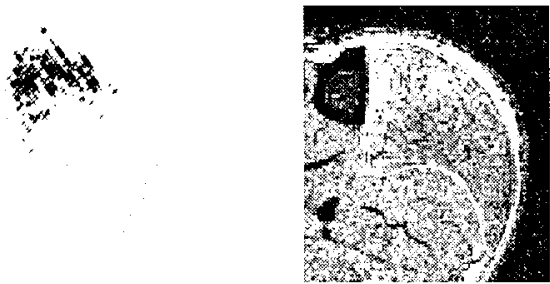

rat 2
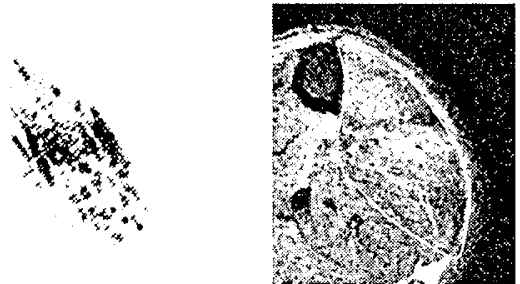

rat 3<smiles>CC(C)(C)C#N</smiles>

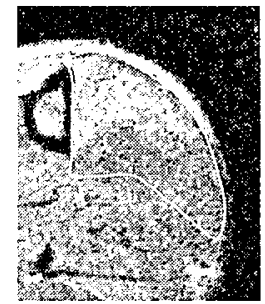

rat 4
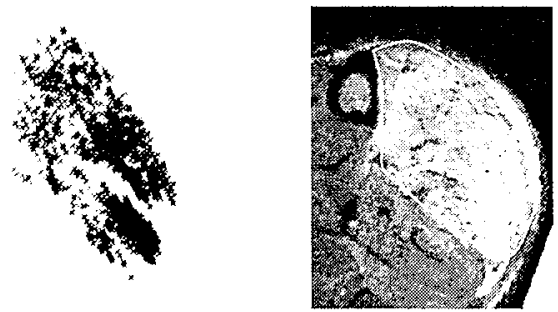

rat 5

Figure 3.3: Damage in transverse histological slices (left) and MR images (right) located at the middle of the indentor. 


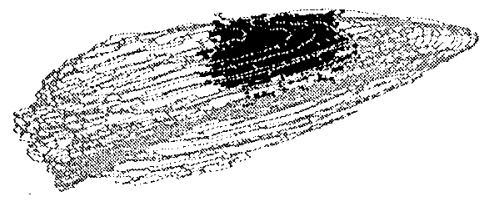

a

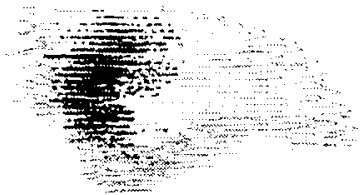

$\mathrm{b}$

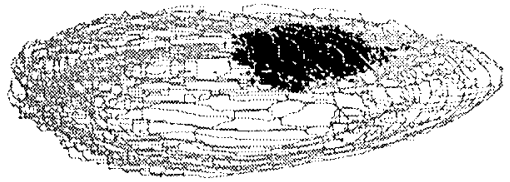

C

Figure 3.4: Three dimensional reconstruction of the tibialis anterior muscle of rat 2 with the damaged area assessed from histological examination seen from oblique (a), front (b) and top (c).

Quantitatively, the correlation between the damaged area assessed in the MR images and the damaged area determined from histological examination was high (fig 3.5, $R^{2}=0.926$ ). The lowest correspondence is found for the muscle which had a small hemorrhage. This hemorrhage resulted in a decrease in signal intensity on the MR images and is thus not included in the determination of the amount of damage with MRI. In the histological slices, however, the area with the hemorrhage showed the

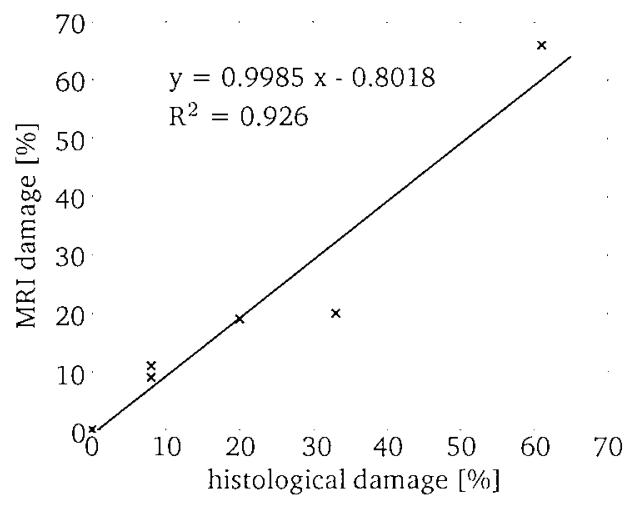

Figure 3.5: Amount of damage assessed with MRI as a function of the amount of damage assessed with histology. The solid line represents the least squares fit through the data of the five rats. 
normal signs of damage and is therefore included in the determination of the amount of damage. When excluding the particular rat from the analysis, the MRI and the histology correlate even better $\left(R^{2}=0.996\right)$.

\subsection{Discussion}

To obtain insight in the aetiology of pressure sores, understanding is required of the relationship between external mechanical loading and the location and amount of tissue damage. To date, tissue damage induced by external loading was determined by histological examination. In this study we demonstrated that T2-weighted highresolution MRI is a promising alternative to evaluate muscle tissue after prolonged transverse loading.

In the MR images a higher signal intensity is visible in the loaded tibialis anterior muscle as compared the unloaded muscles in the same hind limb. The increase in signal intensity on the MR images is found in a localised zone near the place of indentation and clearly coincides with the damage found with histology. Increasing signal intensity on T2-weighted MR images of muscle can reflect a range of pathologies, including edema, necrosis, inflammation and fatty infiltrations (Fleckenstein, 1996). Hence, the imaging method applied in the present study is nonspecific and does not give insight into the damage mechanisms. However, improved insights could be acquired in the same experimental set-up by using other imaging methods.

T2-weighted MR images were also obtained ex vivo on the formalin fixated hind limbs (data not shown). The results of the ex vivo MRI, however, did not correspond to the results of the in vivo MRI or the histology. Moreover, results differed largely for the five rats. In three muscles damage lead to a decrease in signal intensity in the ex vivo MR images, in one muscle an increase in signal intensity was seen, while in the last muscle no abnormalities were visible. Most likely, this variation in results is caused by the formalin fixation, which alters the water compartmentation.

The area of damage determined in the MR images correlates well with the area of damage assessed with histological examination, i.e. more than $90 \%$ of the variation in histological damage can also be detected by employing MRI. The comparison of histology with MRI was limited to two dimensional transverse slices. However, since these slices were representative for the whole muscle, we are convinced that the conclusions remain valid for the three dimensional situation. The correlation was determined from linear regression analysis only based on 6 data points. Still, we thought it to be admissible to employ a regression analysis, as the damaged areas induced in the present study cover a large range, from $0 \%$ to $70 \%$, and are rather 
evenly spread over this range. The large range of damaged areas has the additional advantage that the relation between MRI and histology can be employed in future research, as newly induced damage likely falls within the present range.

The resolution of the MRI is lower than the resolution of the histology, i.e. every pixel in the MRI comprises a number of fibres whereas histological examination can be performed on sub-fibre level. Hence, histological techniques remain to be preferred when sub-fibre accuracy is required or when very small amounts of damage are involved. However, the somewhat lower accuracy, which is still on the submillimeter level, does not outweigh the enormous benefits of MRI, being less labourintensive and non-destructive. MRI is thus a promising alternative in research on pressure sore aetiology, especially in large scale and clinical studies. Moreover, MRI enables follow-up studies to evaluate the development of muscle damage in time. In addition, a large variety of imaging techniques have been developed that can be applied to asses structure, function and metabolism of skeletal muscle. For example, using contrast agents could enhance skeletal muscle fibre lesions (Straub et al., 2000), the components of the multi-exponential T2 relaxation decay reflects the water content and compartmentation in the damaged area (Saab et al., 2000) and ${ }^{31}$ P-NMR diffusion spectroscopy gives insight into changes in the metabolism for damaged tissue (de Graaf et al., 2000).

\section{Acknowledgements}

We gratefully acknowledge Gerard van Vliet for his technical assistance and Erwin Blezer and Boudewijn van der Sanden for their help with the animal experiments. 
Chapter 3 


\section{Chapter 4}

\section{Passive transverse mechanical properties of skeletal muscle}

E.M.H. Bosboom, M.K.C. Hesselink, C.W.J. Oomens, C.V.C. Bouten, M.R. Drost, F.T. Baaijens

Passive transverse mechanical properties of skeletal muscle under in vivo compression, Journal of Biomechanics 34:1365-1368, 2001. 


\section{Abstract}

The objective of the present study is to determine the passive transverse mechanical properties of skeletal muscle. Compression experiments were performed on four rat tibialis anterior muscles. To assess the stress- and strain-distributions in the muscle during the experiments, a plane stress model of the cross section was developed for each muscle. The incompressible viscoelastic Ogden model was used to describe the passive muscle behaviour. The four material parameters were determined by fitting calculated indentation forces on measured indentation forces. The elastic parameters, $\mu$ and $\alpha$, were $15.6 \pm 5.4 \mathrm{kPa}$ and $21.4 \pm 5.7$, respectively. The viscoelastic parameters, $\delta$ and $\tau$, were $0.549 \pm 0.056$ and $6.01 \pm 0.42 \mathrm{~s}$. When applying the estimated material parameters in a three dimensional finite element model, the measured behaviour can be accurately simulated.

\subsection{Introduction}

Continuum models are applied to study the mechanical behaviour and function of skeletal muscle, e.g. in research on pressure sores, impact damage and repetitive strain injuries (Kojic et al., 1998; Martins et al., 1998; Vankan et al., 1998; Gielen et al., 2000). These research topics require information on local stressand strain-distributions inside the muscle, hence the more commonly used one dimensional models for gait analysis are not sufficient. The three dimensional models make use of constitutive equations to describe the passive and active behaviour in both longitudinal and transverse direction. A problem in formulating constitutive equations to describe the passive behaviour is the limited availability of experimental data. In most reported experiments only the longitudinal passive behaviour of the muscle has been determined (e.g. Hawkins and Bey, 1997; Myers et al., 1998). However, additional information is needed on the muscle's transverse mechanical properties.

Generally, the determination of material parameters is based on using test samples with a well defined standardised geometry and loading, so that the material parameters can be assessed via analytical relations. A major drawback, when applying this approach to muscle, is that the preparation of test samples disrupts and damages the muscle fibres. Moreover, the neurovascular supply is impaired, which affects the viability and thus the muscle's mechanical properties. Hence, experiments to determine the transverse properties are to be performed on intact living muscles. The objective of the present study is to determine the passive transverse properties of skeletal muscle. Together with data which are readily available from literature on longitudinal passive and contractile behaviour these data form a complete set 
for a three dimensional characterisation of skeletal muscle. In vivo compression experiments are performed on the rat tibialis anterior muscle (TA). The TA was chosen because its distal part can easily be exposed without damaging either the neurovascular supply or the muscle. The material parameters are obtained by applying a mixed numerical-experimental method. Because the muscle behaves highly nonlinear and viscoelastic the Ogden material model is employed (Ogden, 1982).

\subsection{Experiment}

\subsubsection{Preparation}

Experiments were performed on both the left and right TA of two twelve week old male Brown Norway rats. The rats were anaesthetised with a combination of ketamine (100 $\left.\mathrm{mg} \mathrm{kg}^{-1}\right)$ and xylazine $\left(10 \mathrm{mg} \mathrm{kg}^{-1}\right.$ ) injected subcutaneously. When required, supplemental doses of $10 \mathrm{mg}$ ketamine were supplied intraperitoneally. Body temperature of the rats was maintained at $35-37{ }^{\circ} \mathrm{C}$ using a heating pad. Immediately after the experiment the animals were sacrificed. The Animal Care Committee of the Maastricht University approved the experiments.

Through an incision in the skin the TAs were bilaterally exposed from the proximal aponeuroses to the distal tendons. The fascia covering the TAs was carefully removed. The muscles' most distal $2 \mathrm{~cm}$ were dissected from the surrounding tissues, leaving the distal tendons and the proximal aponeuroses intact. Care was taken to preserve the neurovascular supply. Sutures were stitched to the distal tendons of the TAs and two markers were placed for assessment of the resting length at ankle and knee angles of $90^{\circ}$. The compression experiments were performed on one muscle at a time. The

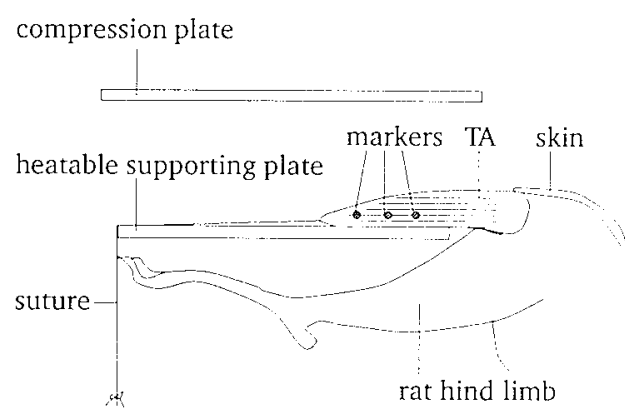

Figure 4.1: Set-up of the compression experiment. 
contralateral muscle was kept in position and the covering skin was repositioned to prevent dehydration while testing the other TA.

Subsequently, the rat was positioned in a mechanical testing device (Zwick 1445). The distal tendon of the TA was cut and the muscle was placed on a supporting plate, heated to $35^{\circ} \mathrm{C}$ (fig 4.1). The muscle's resting length was re-established by securing the suture to a fixation unit using the markers as a reference. Then, three fluorescent spheres $(\varnothing 0.5 \mathrm{~mm}$ ) were attached to the tissue using histoacryl tissue glue. Marker displacements were recorded on video to detect lengthening of the TA. Throughout the entire testing protocol the TA was moistened by dripping a saline solution of $37^{\circ} \mathrm{C}$.

\subsubsection{Protocol}

The TA was compressed between two plates: the supporting plate and a plate fixed to the upper traverse of the mechanical testing device. The indentation force was measured using a load cell (accuracy: $0.05 \mathrm{~N}$ ) and the displacement of the upper traverse was recorded (accuracy: $0.01 \mathrm{~mm}$ ).

The compression plate was visually positioned approximately $1 \mathrm{~mm}$ above the TA, which was defined as the reference position. The displacement of the compression plate was then prescribed following a ramp and hold function, with a ramp speed of $0.25 \mathrm{~mm} \mathrm{~s}^{-1}$ and a hold phase of $20 \mathrm{~s}$. Initially, a $1.5 \mathrm{~mm}$ displacement was applied for each TA. In successive compression experiments the displacement was increased by at least $0.15 \mathrm{~mm}$ and at most $0.50 \mathrm{~mm}$ depending on the indentation force during the previous experiment. An indentation force of $25 \mathrm{~N}$ was considered maximally admissible. In this way, three, four or five levels of compression were applied per TA. Such a series of compression experiments was repeated three times from the lowest to the highest level of compression. All compression experiments were separated by three minutes to allow for relaxation.

\subsection{Finite element model and parameter estimation}

For each TA a plane stress finite element model of the cross section was implemented in MARC. The plane stress approximation was adopted because during the experiments lengthening of the muscle was observed. The geometry was based on a camera image taken from the distal side. The length of the muscle's compressed part was assessed from camera images taken from the medial side and used as thickness in the plane stress model. The horizontal displacement of one node in the middle of the interface of the TA and the supporting plate was suppressed to account for the suture. The vertical displacements of three nodes at the same interface were 
suppressed to prevent free body movements. The TA, the supporting plate and the compression plate were all modelled as contact bodies, applying a direct constraint method for the contact analysis (MARC, 1997). The displacement of the compression plate was prescribed, according to the measured data. At the start of the analysis the compression plate was put in contact with the TA.

To describe the passive muscle behaviour an incompressible Ogden model was employed (Ogden, 1982). In a single mode Ogden model the strain energy function $W$ is:

$$
W=\frac{\mu}{\alpha}\left(\lambda_{1}^{\alpha}+\lambda_{2}^{\alpha}+\lambda_{3}^{\alpha}-3\right)
$$

a function of the principal stretch ratios, $\lambda_{i}$, and the material parameters $\mu\left[\mathrm{N} \mathrm{m}^{-2}\right]$ and $\alpha[-]$. Viscoelasticity was implemented in this constitutive model by means of a Prony series expansion:

$$
S=(1-\delta) \frac{\partial W}{\partial \boldsymbol{E}}+\int_{0}^{t} \delta \frac{\partial W}{\partial \boldsymbol{E}} e^{-(t-\xi) / \tau} d \xi
$$

where $S$ is the second Piola Kirchhoff stress, $\boldsymbol{E}$ is the Green Lagrange strain and $\delta[-]$ and $\tau[s]$ are viscoelastic material parameters.

The material parameters, $\mu, \alpha, \delta$ and $\tau$ were determined by fitting modelling results on experimental data applying a numerical-experimental iterative procedure (Oomens et al., 1993). For this a least squares objective function, $J$ :

$$
J=(y-h(\theta))^{T}(y-h(\theta))
$$

is minimised with respect to the material parameters, $\theta$. In the present study $y$ contains the measured indentation forces and $h(\theta)$ contains the calculated forces for given estimates of $\theta$.

To test the limitations of the two dimensional plane stress approach in the parameter estimation one three dimensional forward analysis was performed with the parameter set resulting from the two dimensional analysis.

\subsection{Results}

The muscle behaves highly nonlinear and viscoelastic (fig 4.2). This behaviour can very well be described by means of the Ogden model. The material parameters converged to stable values within 10 iterations independent of the chosen initial values. The mean and standard deviations for the elastic parameters, $\mu$ and $\alpha$, were $15.6 \pm 5.4 \mathrm{kPa}$ and $21.4 \pm 5.7$. For the viscoelastic parameters, $\delta$ and $\tau$, the mean and standard deviations were $0.549 \pm 0.056$ and $6.01 \pm 0.42 \mathrm{~s}$. The parameter values for the individual rats are summarised in table 4.1. 



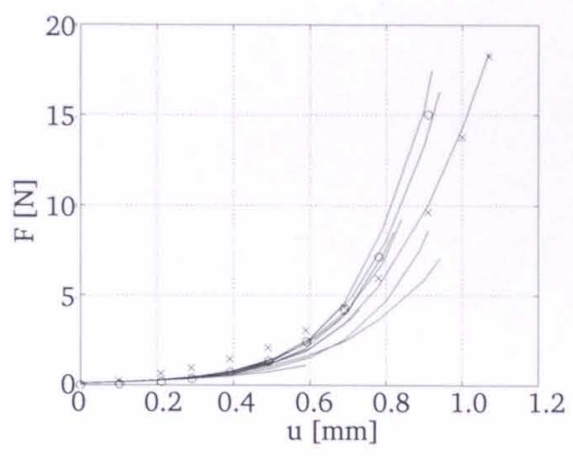

a

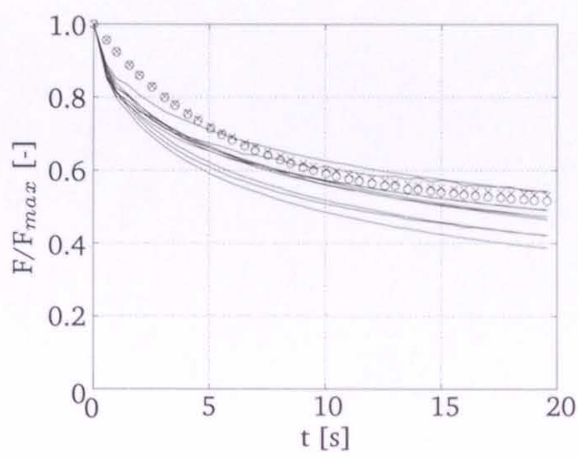

b

Figure 4.3: Comparison of the measured (-) and calculated indentation forces using the plane stress model $(\mathrm{x})$ and the three dimensional FE model (o) during the loading (a) and relaxation phase (b). Results of the right TA of rat 2 .

\subsection{Discussion}

A method for an in vivo determination of passive transverse properties of skeletal muscle in the rat TA is described. These data are indispensable for the development of three dimensional continuum models for muscle and were to date not available in literature. Special care was taken to maintain the viability of the muscle tissue during the experiments by preserving the neurovascular supply. Determination of the material parameters was only possible by means of a numerical-experimental method, because the protocol led to an inhomogeneous stress- and strain-distribution in the TA. The incompressible Ogden model extended with viscoelasticity was employed to describe the muscles behaviour and seems appropriate to describe the nonlinear viscoelastic behaviour. The set-up for in-vivo characterisation worked quite well, but can be improved by measuring internal muscle strains, f.e. by means of MRI-tagging. 
Chapter 4 


\section{Chapter 5}

\section{Cell deformation as a trigger for pressure sore related muscle damage}

E.M.H. Bosboom, C.W.J. Oomens, C.V.C. Bouten, H. Kuipers, F.P.T. Baaijens

Cell deformation as a trigger for pressure sore related muscle damage, Annals of Biomedical Engineering, 2001, submitted. 


\section{Abstract}

We investigated the hypothesis that prolonged cell deformation is the primary trigger for the onset of tissue damage related to pressure sores. If a direct relationship between cell deformation and tissue damage exists, the maximum shear strain distributions in the tissue must coincide with the amount and location of initial tissue damage. In animal experiments the tibialis anterior muscle and overlying skin were compressed between an indentor and the tibia during 2 hours. Histological techniques and magnetic resonance imaging were applied to determine the amount and location of the induced muscle damage. The experiments were simulated with a finite element model to assess the maximum shear strain distributions in the muscle during loading. Despite the strictly controlled experimental and loading conditions a large variation in susceptibility for muscle damage was found, which can not be explained by the risk factors commonly identified as relevant for pressure sore development. Although the shear strain distribution showed some coincidence with the area of muscle damage, the results were not convincing enough to reject nor to adopt the hypothesis on cell deformation as the primary trigger for pressure sore related muscle damage.

\subsection{Introduction}

Pressure sores are localised areas of soft tissue breakdown, arising from prolonged mechanical loading at the interface between skin and supporting surfaces. The soft tissue breakdown starts at the cellular level and is characterised by nuclear pyknosis and an early disintegration of the contractile proteins in the cells, followed by inflammatory reactions (Kosiak, 1961; Nola and Vistnes, 1980; Salcido et al., 1994; Bosboom et al., 2001a). Pressure sores can occur, for example, when patients are bedridden, wheelchair bound or wearing prostheses. The sores are depressing for the patient and can be very painful, especially in the early stages. Massive efforts in pressure sore prevention have not led to a reduction of the prevalence; around $10 \%$ of all patients in acute care hospitals have pressure sores (Barczak et al., 1997). This is at least partly due to a limited knowledge on pressure sore aetiology. Since pressure sores are primarily caused by interface loading, prevention mainly aims at reducing these external loads. It is, however, not known how the external loads are transferred to the underlying tissues. In addition, prevention is complicated because pressure sores can develop either superficially or from within the deeper tissue layers (Bliss, 1993). Superficial sores initiate in the skin and are thus easily detected. Deep pressure sores, on the other hand, start to develop near bony prominences and 
progress towards the surface. Hence, considerable necrosis can be present without any visible signs.

As a guide to pressure sore prevention, animal models have been developed that aim at determining a threshold value for external loads that will result in tissue damage (Kosiak, 1961; Daniel et al., 1981; Salcido et al., 1994; Goldstein and Sanders, 1998; Peirce et al., 2000). All these animal studies resulted in different damage thresholds, which are difficult to compare because of a diversity in laboratory animals and methods and regions of load application. A means of overcoming these differences would be to relate the externally applied loads to the local internal stresses and strains, since these local stresses and strains act at the cellular level, where damage initiates. The relation between external global loading at the skin surface and the local mechanical conditions within tissues can be complicated especially near complex geometries, such as bony prominences (Dodd and Gross, 1991; Dabnichki et al., 1994).

Three hypotheses are commonly postulated on how mechanical loading leads to pressure sore formation, but to date none of them is fully verified. The first and mostly suggested hypothesis is that pressure sores are caused by local ischacmia and/or reperfusion following occlusion of capillaries (Kosiak, 1961; Daniel et al., 1981; Salcido et al., 1994; Pcirce et al., 2000). The onset of pressure sores, however, is only partly explained by this theory, as tissue can remain viable without circulation for an extended length of time, while pressure sores develop much faster. The sccond hypothesis aims at a disturbance of the metabolic equilibrium around a cell due to impaired interstitial fluid flow and lymphatic drainage (Krouskop, 198:3; Reddy, 1990) and is based on studies using phenomenological models. The third hypothesis states that prolonged cell deformation is an important trigger for the onset of tissue damage (Ryan, 1990; Bouten et al., 2001). Changes in the mechanochemical environment of the cell may then enhance the development of tissue degeneration. Indeed, in-vitro experiments on cultured muscle cells demonstrate that prolonged compressive deformation results in cell damage, even when oxygen and nutrient supply is maintained (Bouten et al., 2001). However, this theory has not been evaluated in living tissuc.

The aim of the present paper is to test whether the cell deformation hypothesis may be valid in vivo at the tissue level. If a direct relationship exists between cell deformation and tissue damage, the maximum shear strain distributions in the tissue must coincide with the amount and location of initial tissue damage. The shear strain distributions within the tissues under external loading can be assessed with a finite element model. The amount and location of damage can be determined using histological techniques or magnetic resonance imaging (MRI). 'The present paper is focused on muscle, as muscle tissuc is more susceptible to mechanical loading than skin (Nola and Vistnes, 
1980; Daniel et al., 1981) and the most severe pressure sores often initiate in muscle (Bliss, 1993). If a clear relationship between strain and damage distribution exists, such a result can be used to prevent pressure sores, for instance in the design of patient supporting systems.

\subsection{Methods}

\subsubsection{Animal experiments}

The animal model was described previously (chapter 2, Bosboom et al., 2001a). In brief, experiments were performed on five male anaesthetised Brown Norway rats weighing 200 - 230 grams. Prior to the experiment the hairs on the right tibialis anterior region of a rat were cut, while care was taken not to damage the skin. The rat was then placed supine in a loading apparatus, consisting of a unit for fixation of the tibia of the right hind limb, and a unit for load application (fig 5.1). The tibia was fixed by taping the foot on a footplate and by clamping the medial and lateral condyles between two concave surfaces. Loading was applied using a pneumatically driven indentor with a rounded contact surface $(\varnothing 3.0 \mathrm{~mm})$. The indentor was placed halfway between foot and knee perpendicular to the skin overlying the tibialis anterior muscle, at an angle of approximately $40^{\circ}$ with the horizontal. In this way, the tibialis anterior muscle and overlying skin were compressed between the indentor and the tibia. In the present study, a load of $2 \mathrm{~N}$ at skin surface, resulting in an average interface pressure of $250 \mathrm{kPa}$, was applied for 2 hours. After the completion of the

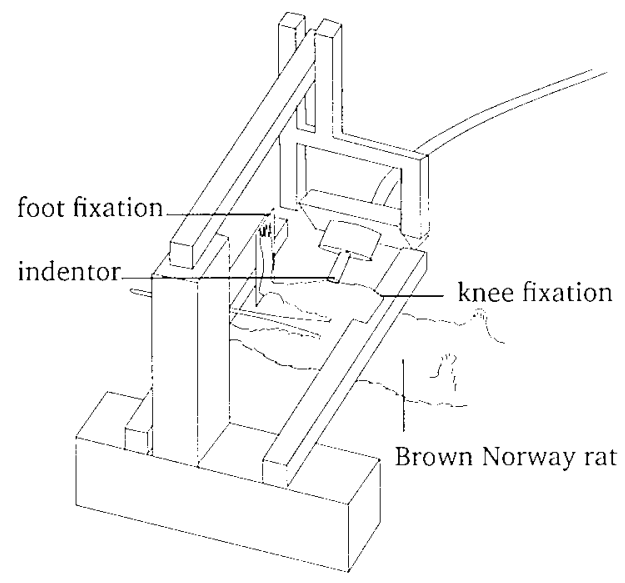

Figure 5.1: Loading apparatus consisting of unit for load application and a unit for fixation of the rat's hind limb. 
loading session, the rat was removed from the loading apparatus, observed until recovered from anaesthesia and allowed to move freely for the next 24 hours. The rat was then anaesthetised once more and placed in a MRI set-up. In vivo MR images of both the loaded and control hind limb were obtained applying a T2-weighted spin echo sequence ( $\mathrm{TE}=45 \mathrm{~ms}, \mathrm{TR}=5 \mathrm{~s}$ ). The transverse images had a field of view of $30 \mathrm{~mm} * 30 \mathrm{~mm}$ and a resolution of $256 * 256$ pixels. Afterwards the rat was sacrificed and perfusion fixated with formalin. The tibialis anterior muscles were excised, dehydrated and embedded in plastics (Technovit 7100, Kulzer). Finally, the muscles were cut into $3 \mu \mathrm{m}$ thick longitudinal slices and stained with toluidine blue for histological examination. The experimental protocol was approved by the Animal Care Committee of the Maastricht University.

\subsubsection{Finite element model}

To asses the local mechanical conditions in the muscle during the animal experiments, finite element simulations were performed with the software package MARC (MARC, 1997). The geometry of the model was based on MR images. As the tibialis anterior muscle forms a functional unit with the extensor digitorum longus muscle, surrounded by a thin fascia, these two muscles were modelled as one structure, hereafter referred to as muscle. The skin thickness was measured ex vivo and modelled as a $0.7 \mathrm{~mm}$ thick layer covering the muscle. The rats had little subcutaneous fat, hence this layer was not modelled separately. The muscle and

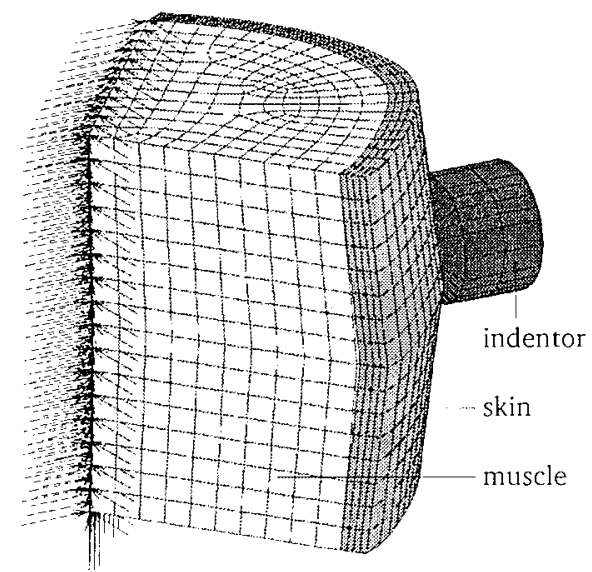

Figure 5.2: Three dimensional finite element mesh of the muscle, skin and indentor; The arrows indicate the suppressed displacements at the interface with the tibia and membrana interossea. 
skin were modelled with respectively 2592 and 1408 first order hexahedral elements (fig 5.2). These elements were based on the Herrmann variational principle to prevent locking due to incompressibility.

To describe the material behaviour of skin and muscle an incompressible Ogden model was employed. The strain energy function $W$ of this model:

$$
W=\sum_{n=1}^{N} \frac{\mu_{n}}{\alpha_{n}}\left(\lambda_{1}^{\alpha_{n}}+\lambda_{2}^{\alpha_{n}}+\lambda_{3}^{\alpha_{n}}-3\right)
$$

is a function of the principal stretch ratios, $\lambda_{i}$, and the material parameters $\mu_{n}\left[\mathrm{~N} \mathrm{~m}^{-2}\right]$ and $\alpha_{n}[-]$. Viscoelasticity is implemented in this constitutive model by means of a Prony series expansion:

$$
S=\left(1-\sum_{m=1}^{M} \delta_{m}\right) \frac{\partial W}{\partial \boldsymbol{E}}+\sum_{m=1}^{M} \int_{0}^{l} \delta_{m} \frac{\partial W}{\partial \boldsymbol{E}} e^{-(t-\xi) / \tau_{m}} d \xi
$$

where $S$ is the second Piola Kirchhoff stress, $E$ is the Green Lagrange strain and $\delta_{m}[-]$ and $\tau_{m}$ [s] are viscoelastic material parameters. First order models were used for both the elastic and viscoelastic behaviour of skin and muscle, i.e. $N=1$ and $M=1$. The material parameters of muscle were taken from in vivo compression experiments on a rat tibialis anterior muscle (chapter 4, Bosboom et al., 2001b). To date no reliable data are available on the material behaviour of rat skin under compression. As a first estimate, material parameters were obtained by fitting the Ogden model on experimental results of pig skin under compression taken from Oomens (1985). The applied material parameters are summarised in table 5.1. The tibialis anterior muscle is bound to the tibia with fascia. Hence, for the muscle all nodal displacements were suppressed in the surface contacting the tibia. Moreover, the muscle is supported by the membrana interossea, a stiff collagenous membrane between tibia and fibula and displacements were also suppressed at this interface. Contact between the indentor and the skin and between the skin and the muscle was modelled by applying a direct constraint method. The finite element model consisted of three contact bodies: the rigid indentor, the deformable skin layer and the deformable muscle tissue. Relative sliding of the skin along the muscle and indentor

Table 5.1: Applied material parameters of the incompressible viscoelastic Ogden model ( $N=1$ and $M=1)$ for skin and muscle.

\begin{tabular}{l|cccc} 
Tissue & $\begin{array}{c}\mu \\
{[\mathrm{kPa}]}\end{array}$ & $\alpha$ & $\delta$ & $\tau$ \\
\hline muscle & 15.6 & 21.4 & 0.55 & {$[\mathrm{~s}]$} \\
\hline skin & 16.0 & 10.0 & 0.50 & 20.0
\end{tabular}


was enabled, whereas friction was neglected. The tissues were incrementally loaded by prescribing the motion of the rigid indentor. The total displacement was chosen such that the contact force corresponded with the $2 \mathrm{~N}$ applied during the animal experiments.

This model had four major uncertainties: employing an isotropic material law for muscle, the material properties for skin, the direction of load application and the boundary conditions at the interface with the membrana interossea. To asses how these choices affected the results, extra simulations were performed. Firstly, isotropic and anisotropic behaviour were compared while employing linear elastic material laws, as the Ogden model could not easily be adjusted to describe anisotropic behaviour. Secondly, a simulation was performed with a higher skin stiffness ( $\mu=133 \mathrm{kPa})$, chosen such that initially skin was four times stiffer than muscle. Thirdly, the indentation angle was changed from $40^{\circ}$ to $30^{\circ}$, so that two different loading directions could be compared. Finally, muscle displacements at the interface with the membrana interossea were left free. In addition, simulations were performed in which the membrana interossea was modelled. The membrane consists mainly of collagen, hence for the material properties ligament properties were taken as a starting point. To avoid a high aspect ratio of the three dimensional elements, the membrane was modelled 25 times too thick, i.e. as a $1 \mathrm{~mm}$ thick layer. To approach the correct behaviour under bending, the E-modulus was adjusted to $\frac{1}{25}$ of literature values determined by Cabaud et al. (1980), i.e. $\mathrm{E}=10 \mathrm{MPa}$ and $\nu=0.5$.

\subsection{Results}

\subsubsection{Animal experiments}

For all five rats the loading protocol resulted in muscle damage, demonstrated histologically by a loss of cross-striation and infiltration of mononuclear cells (fig 5.3). These markers correspond to previously described signs of damage (Kosiak, 1961; Nola and Vistnes, 1980; Salcido et al., 1994). On the MR images muscle damage lead to a higher signal intensity (fig 5.4). In a separate study, it was shown that the muscle damage determined with histological examination corresponds to damage determined with MRI (chapter 3).

In all five loaded muscles damage was found throughout the whole depth from skin to tibia, while mainly the ventral part of the muscle was damaged. Moreover, the damaged area was elliptically shaped and 1.5 to 2.5 times larger in longitudinal direction than in transverse direction (fig 5.5). 


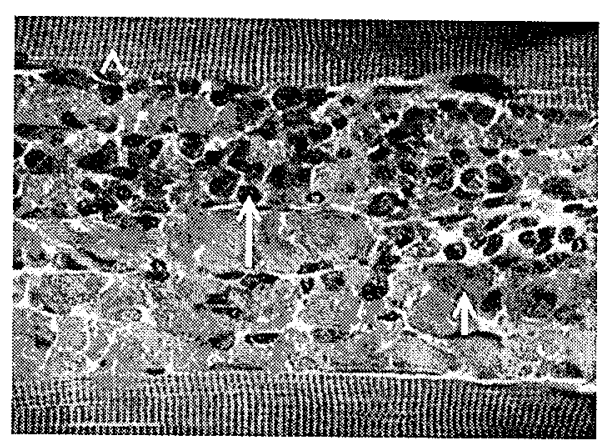

$10 / \mathrm{m}$

Figure 5.3: Longitudinal histological section of muscle showing the typical cross-striated appearance of skeletal muscle (arrowhead), a loss of crossstriation of muscle fibres in the damaged area (small arrow) and the infiltration of mononuclear cells (large arrow).

However, despite the strictly controlled loading protocol, large variations in the amount of damage were observed between rats, i.e. damage was localised and diffuse in nature (fig 5.4). In rat no. 1 damage was highly localised in a volume of about $5 \%$ of the tibialis anterior muscle, whereas $90 \%$ of the muscle of rat no. 5 was more diffusely damaged. The damaged area in the tibialis anterior muscle of rat no. 2 is representative for the 'average' damaged area of the five rats.

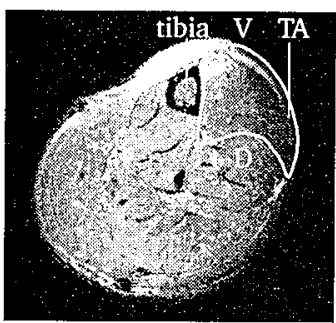

a

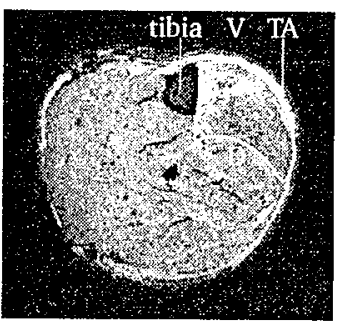

b

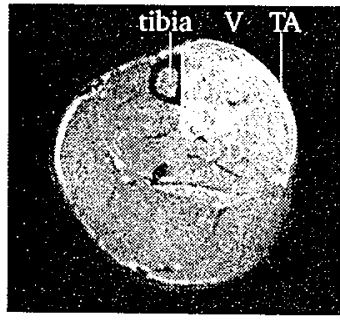

c.

Figure 5.4: Transverse MR images of the loaded hind limb of rat 1 (a), rat 2 (b) and rat 5 (c); Bright areas in the TA correspond to sites of skeletal muscle damage (V:ventral, D:dorsal). 


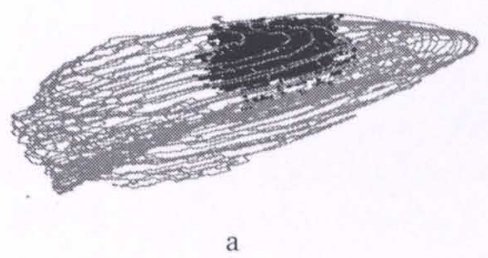

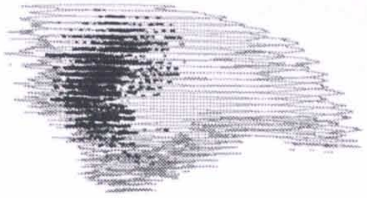

b

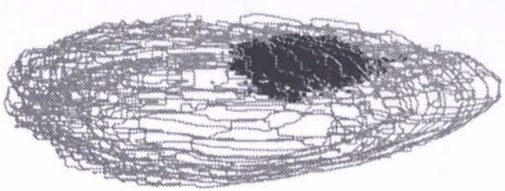

C

Figure 5.5: Three dimensional reconstruction of a tibialis anterior muscle with the damaged area assessed from histological examination seen from oblique (a), front (b) and top (c); Results of rat 2.

\subsubsection{Finite element model}

The maximum shear strain was highest (24\%) just underneath the skin at the place of indentation (fig 5.6). Shear strains decreased further from the indentor, while the shear strain distribution was somewhat elongated in the direction of load application. In the muscle's longitudinal direction, the shear strain distribution was circular near
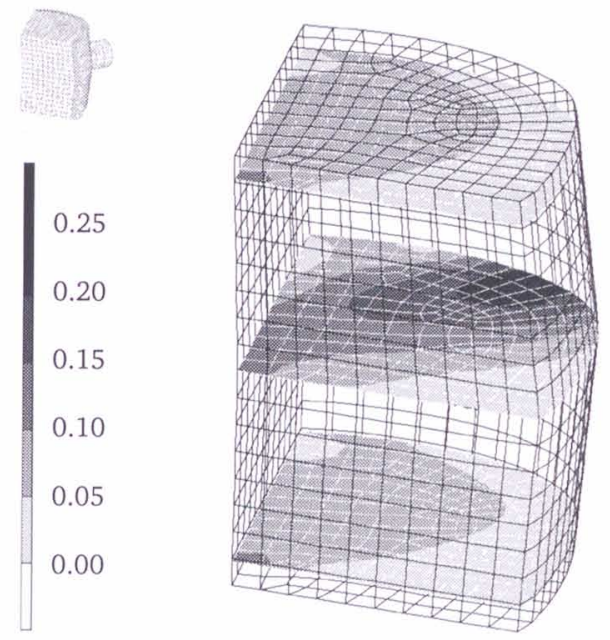

Figure 5.6: Maximum shear strains in transverse sections of the muscle at an indentation force of $2 \mathrm{~N}$. 
the indentor and elliptical near the membrana interossea being larger in longitudinal direction than in transverse direction with a ratio of 1.5.

Employing anisotropic elastic material behaviour for muscle did not change the results as compared to employing linear elastic behaviour. Moreover, the shear strains in the muscle were hardly $(<8 \%)$ affected by changing either the skin stiffness or the loading direction. However, different boundary conditions at the interface with the membrana interossea had a major effect on the results (fig 5.7). When the displacement of the muscle at the membrana interossea was left free, the shear strain distributions were shifted ventrally to the part of the muscle located between indentor and tibia. The results of the simulation, in which the membrana interossea was modelled, are in-between the results of the simulations with fixed and free boundary. Unfortunately, because of convergence problems, the latter simulation could only be performed up to a reaction force of $1.2 \mathrm{~N}$. Still, the differences are significant and conclusions on the tendencies remain valid.
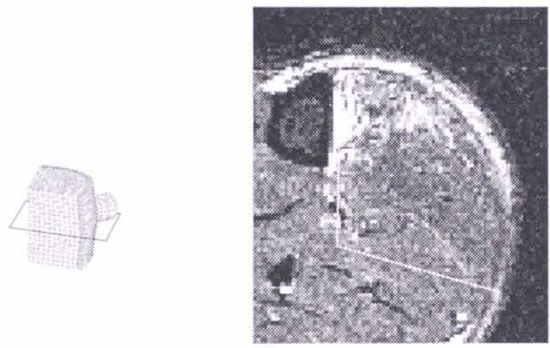

a

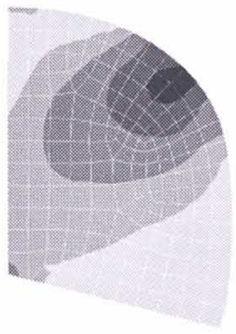

b

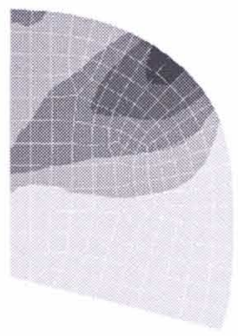

C

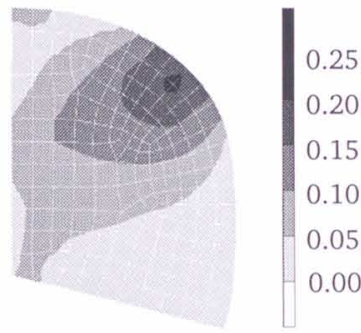

d

Figure 5.7: Comparison of the area of muscle damage in a transverse section (a) with maximum shear strain distributions for the reference model (b), the model with free displacements at the membrana interossea (c) and the model in which the membrana interossea was modelled (d) at an indentation force of $1.2 \mathrm{~N}$. 


\subsection{Discussion}

The present study was performed to evaluate whether prolonged cell deformation triggers muscle damage related to pressure sores. If that is the case, maximum shear strain distributions in the muscle must coincide with the amount and location of initial muscle damage. When considering the results of the animal experiments, it is clear that such a comparison is complicated by the large variation in damage found for the different rats. It is common knowledge that results of animal experiments always show biological variation. Still, the variation in the present experiments is striking. From clinical observations, it is known that the susceptibility of patients to develop pressure sores differs largely, but usually these differences can be explained by a different underlying pathology (Bliss, 1993) or differences in additional risk factors, like age, mobility and nutritional state. However, not all individual differences can be captured in this way (Meijer et al., 1989). In the present study, experiments were performed with healthy rats of the same sex, age and weight and under equal conditions. Nevertheless, a large variation in susceptibility for muscle damage resulted. This finding needs further study as the amount of tested animals was limited and only one loading protocol was applied. However, if differences in susceptibility cannot be explained with underlying pathologies or known risk factors, this may have large consequences for pressure sores prevention.

Despite the interspecimen variations, in all loaded muscles damage was mainly found in the ventral part of the muscle between skin and tibia. In addition, the damaged area was 1.5 to 2.5 times larger in longitudinal than in transverse direction. These common features can be compared to the maximum shear strain distribution in the finite element model. Most simulations resulted in shear strain distributions not corresponding to the location and amount of muscle damage. In these simulations, the displacements at the interface between the muscle and the membrana interossea were fixed. However, releasing the restrictions at this interface and modelling the membrane as a plate with bending stiffness, shifted the shear strain contours ventrally, so that the shear strain distribution showed a better correspondence with the damaged area.

Although the calculated shear strain distributions showed some overlap with the area of muscle damage, the result is not convincing enough to conclude that cell deformation is the major trigger for muscle damage. It is obvious that the obtained results require further research. Firstly, a validation of the finite element model is necessary, e.g. with deformations in the muscle measured during loading by applying MRI tagging (Maenhout et al., 2001). In addition, more animal experiments are to be performed to obtain more insight in the susceptibility for muscle damage and to study the development of damage in time. This became feasible, since we demonstrated 
that MRI can be applied to assess muscle damage (chapter 3). MRI is less labourintensive than histology, thus enabling experiments on a larger scale. In addition, MRI is not destructive and hence follow-up studies are possible. Finally, we believe that the present results are an incentive for more fundamental research on the aetiology of pressure sores. 


\section{Chapter 6}

\section{General discussion}




\subsection{Introductory remarks}

Pressure sores are primarily caused by prolonged mechanical loading at the interface between skin and supporting surfaces, but the underlying pathways leading to tissue damage are poorly understood. The external mechanical loading leads to local stresses and strains within the tissues. However, the local stresses and strains are related to the external loads in a complicated, non-trivial and nonlinear way, since they depend on tissue geometry and material properties. In addition, it is not known how the tissue layers respond to the mechanical loading and how this eventually can result in tissue damage. Three hypotheses are proposed, which focus on a different functional unit of the tissue, namely 1) localised ischaemia due to the occlusion of blood vessels, 2) impaired transport of nutrients through the interstitium and 3) deformation of the cells.

The aim of the present thesis was to obtain more insight into the relationship between prolonged mechanical loading and localised muscle damage. We focused on muscle tissue, since muscle is more sensitive to mechanical loading than skin (Nola and Vistnes, 1980; Daniel et al., 1981) and the most severe pressure sores often initiate in the deeper muscle layers (Bliss, 1993). A combined approach was chosen involving both animal experiments and finite element modelling. Animal experiments were performed to relate external mechanical loading to the location and amount of muscle damage. The finite element model was developed to assess the local stresses and strains within the muscle in response to the external loading during the experiments. Comparison of the local muscle damage with the local mechanical conditions within the tissue should then provide information on the local mechanical parameters critical for the onset of damage and enable a better prediction of the consequences of external loading for tissue damage.

\subsection{Animal model}

To obtain more insight in the effect of mechanical loading on tissue, information is needed on the amount and the location of tissue damage induced by the loading. Because former animal models on the aetiology of pressure sores, were limited to the question whether or not damage occurred, we developed a new rat model and new damage analysis techniques that can be used to relate controlled external loading to localised muscle damage (chapter 2). Results showed that the developed model can indeed be used to induce localised muscle damage by applying a controlled load and that the amount and location of damage can be assessed using the newly developed techniques. With this approach valuable insights with regard to the localised muscle damage were obtained. The induced muscle damage was found in a localised zone 
near the place of indentation and ran from superficial to deep muscle layers. In addition, it is remarkable that in 'damaged' regions not necessary all muscle fibres were affected. Commonly, in the middle of the damaged area all muscle fibres show lysation, but at the borders damaged and undamaged fibres alternate. This might indicate at a protective mechanism aimed at maintaining tissue function. Additional research, however, should elucidate whether the alternating pattern is indeed a consequence of an apoptotic process in which some fibres break down to relieve other fibres, or originates from the structural heterogeneity of the tissue.

Rats were selected for the experiments, because the reconstruction of the loaded muscle required a small animal. Rats have been used as a model to study pressure sore aetiology in older (Husain, 1953; Kosiak, 1961) as well as recent studies (Salcido et al., 1994; Peirce et al., 2000), but a commonly raised objection is that the skin of rats differs from human skin (Daniel et al., 1981; Goldstein and Sanders, 1998). The present research, however, focuses on muscle tissue and rat models are commonly used to study skeletal muscle functioning, e.g. in research on exercise induced damage (Hesselink et al., 1996) and deformation during contractions (van Donkelaar et al., 1999). In addition, as the soft tissue layers affect the transfer of the mechanical load to the muscle, differences in material properties and geometry are accounted for in the finite element model so that the local stresses and strains within the muscle tissue during loading are accurately determined. Still, when in future research the responses of skin to mechanical loading are studied, the choice of the rat as an animal model needs to be reconsidered. Moreover, one should obviously be careful when extrapolating results of animal studies to human subjects and clinical situations.

The present research was performed to obtain insight into the relationship between mechanical loading and the onset of damage. The loading applied in the animal experiments was therefore chosen such that small amounts of muscle damage were induced instead of deep pressure sores affecting all tissue layers. The kind of muscle damage found in the experiments consisted of a loss of cross-striation and infiltration of macrophages and were in fact a sign of regeneration of the tissue. These damage markers were therefore visible only 24 hours after loading. Obviously this time lapse is too long for application of this method as a diagnostic tool in clinical situations. For this specific purpose markers able of signalling early cellular stress leading to tissue damage should be applied. The current histological techniques can then be employed to define damage thresholds, in terms of magnitude and duration of the mechanical loading, whereas other techniques, such as biochemistry and immunohistochemistry, should be applied to determine early markers of tissue breakdown at these thresholds. In addition, future work should pay attention to the application of knock-out animals. As in these animals certain mechanisms involved in the pathways of tissue breakdown can selectively be down-regulated, more insight in the pathophysiology of the muscle damage can be obtained. 
To evaluate the muscle and assess the location and amount of damage both histological techniques and high-resolution T2-weighted MRI could be applied (chapter 3). However, the resolution of the MRI is limited to about ten muscle fibres and hence for a precise determination of the damaged muscle volume histology remains preferred. On the other hand, MRI limits the time needed for the quantification and localisation of damage and therefore enables experiments on a larger scale. Moreover, MRI is non-destructive and thus has the potential both in follow-up studies to evaluate the development of muscle damage in time, and in clinical studies. In further research, other MRI techniques, such as 'H-MRS and ${ }^{31} \mathrm{P}$-MRS could give information on how prolonged loading affects the muscle's metabolism. In addition, more insight into the pathways leading to muscle damage could be acquired by studying the components of the multi-exponential T2 relaxation time, as these components reflect the water content and compartmentation (Saab et al., 2000).

In chapter 5 a high load of $250 \mathrm{kPa}$ at skin surface was applied for a short time. Despite the strictly controlled experimental and loading conditions, a large variation in damage was found for the different rats, both in the amount and the distribution of the damage. It is too early to draw any hard conclusions from this finding, as the amount of tested animals was limited and the pathways leading to tissue breakdown are still unclear. However, it could well be that there are large individual differences in the pathways leading to muscle breakdown, for example in the production or production rate of proteins needed to adverse the muscle breakdown.

\subsection{Finite element model}

The finite element model was aimed at determining the mechanical conditions within the muscle during loading. From the results in chapter 5 it can be concluded that this aim was met. The shear strains in the muscle ranged between $0-20 \%$, which is a relevant range for pressure sore related research as these shear strains are comparable to strains that occur in buttocks, when people are lying on supporting cushions (Reger et al., 1990). Moreover, in vitro experiments on cultured muscle cells demonstrated that $20 \%$ strain results in a significant increase in muscle cell damage (Bouten et al., 2001).

Our three dimensional finite element model makes use of constitutive equations to describe the passive behaviour of the muscle. A problem, however, was that for the transverse behaviour of skeletal muscle no data were available in literature. Hence, experiments were performed to determine the passive transverse properties, in which special care was taken to maintain the viability of the muscle tissue during the 
experiments by preserving the neurovascular supply (chapter 4). Because the protocol led to an inhomogeneous stress- and strain-distribution in the muscle, determination of the material parameters was only possible by means of a numerical-experimental method. Hence, the material parameters of an incompressible Ogden model were obtained from fitting the modelling results on experimental data. The experimental set-up worked quite well and when applying the estimated material parameters in a three dimensional finite element model, the measured behaviour could be accurately simulated.

Yet, other modelling uncertainties remained, i.e. the isotropy in the material law employed for the passive muscle, the transverse properties for skin, the direction of load application and the boundary condition at the membrana interossea, a stiff collagenous membrane between tibia and fibula. To determine the effect of the choices made for these model parameters, extra simulations were performed (chapter 5). From these parameter variations, it could be concluded that the majority of the above-mentioned choices hardly affected the results $(<8 \%)$. However, changing the boundary condition at the interface between muscle and membrana interossea had a major effect. To be able to better define the boundary conditions at this interface, the deformation of muscle under loading should be determined in future studies.

Still, before any hard conclusions can be drawn, the finite element model needs validation. In the present research, a first attempt was made by measuring the interstitial fluid pressure (chapter 2). However, results were inconsistent (data not shown) and the measurements largely interfered with the occurrence of damage. A more promising method for a future validation of the model, is the measurement of deformations in the muscle by applying MRI tagging techniques (Maenhout et al., 2001).

\subsection{Deformation as a trigger for pressure sores?}

By describing the relationship between prolonged mechanical loading and localised muscle damage an attempt was made to provide more fundamental knowledge about the aetiology of pressure sores. Such knowledge is important for a better understanding of the pathology of the clinical condition and essential for the prevention of pressure sores. So far the limited studies focusing on the aetiology of pressure sores aimed at different functional tissue units which are considered to be critical for tissue breakdown, namely the blood vessels, the interstitium and the cells. It can be argued, however, that the related phenomena, i.e. ischaemia, interstitial changes and cell deformation, are all due to local tissue deformation. 
Alternatively, the nature of the mechanical loading is considered to be a key factor in tissue breakdown. It is generally accepted that superficial pressure sores are predominantly caused by shear stresses, whereas deep sores are mainly resulting from prolonged compression. However, in these cases tissue damage is again triggered by tissue deformation. This is illustrated by our study, where a localised pressure of $250 \mathrm{kPa}$ induced muscle damage as the localisation of the pressure resulted in deformation of the muscle. An equally high hydrostatic pressure, on the other hand, does not deform the tissues and hence does not induce tissue damage. This can be seen from divers working at a depth of over 25 meter, who do not develop pressure sores.

By accepting deformation as a trigger for tissue breakdown the pathways leading to tissue breakdown still remain unclear. Possibly, all tissue units are relevant, but the relative contribution of each unit to tissue breakdown remains to be elucidated. In the developed rat model not only the muscle cells are subjected to a prolonged deformation but also the blood vessels and the interstitium. Hence, the rat model does not discriminate between the three hypotheses on pressure sore aetiology aiming at ischaemia, interstitial changes and cell deformation. Similar to the rat model, the developed finite element model does not discriminate between the different functional units of the tissue as the muscle was modelled as bulk tissue.

In chapter 5 we focused on the hypothesis stating that prolonged cell deformation is an important trigger for the onset of tissue damage. This theory was previously supported by in vitro experiments on cultured muscle cells (Bouten et al., 2001), but not evaluated in living muscle tissue. If a direct relationship existed between cell deformation and muscle damage at a tissue level, the maximum shear strain distributions in the muscle should coincide with the location of initial muscle damage. Although some overlap was found between the calculated shear strain distributions and the area of muscle damage, the result was not convincing and neither sufficient enough to conclude that cell deformation is the major trigger for muscle damage.

To investigate the relative role of each functional tissue unit in muscle breakdown an alternative hierarchical approach is required involving both in vivo models and in vitro models. In this approach models should range from single cell studies to in vivo animal studies. Experiments with single cells give insight into the response of cells to mechanical loading. In an experimental model of cells in an extracellular matrix environment, next to the response of the cells also the protective influence of the matrix and the transport of nutrients through the interstitium can be studied. Finally, in animal models insight can be obtained on the role of blood perfusion for tissue breakdown, for example by applying measurement techniques like laser Doppler anemometry or magnetic resonance anemometry. The mechanical conditions of these experimental models can be coupled by multilevel finite element models (Breuls et al., 2001). 
The afore-mentioned hierarchical approach is a solid means of obtaining a clear understanding of the pathways leading to tissue breakdown and the relative role of the functional units of the tissues. This knowledge is required to improve pressure sore prevention and hence to reduce the prevalence. When it is clear how external loads lead to tissue breakdown, a sensible choice can be made for the reduction of the external loads in terms of duration or magnitude. In addition, it might even be possible to improve the load bearing capacity of the tissues and find a treatment for pressure sores. Finally, experiments on all levels of complexity from cell to composite tissue may help in finding markers able of signalling cellular stress at the beginning of the pathways leading to tissue breakdown. Such a marker could well be used in the development of diagnostic tools for pressure sores to be used in clinical applications. 
60 Chapter 6 


\section{References}

D.L. Bader and S.H. White. The viability of soft tissues in elderly subjects undergoing hip surgery. Age Ageing, 27:217-221, 1998.

C.A. Barczak, R.I. Barnett, E. Jarczynski Childs and L.M. Bosley. Fourth national pressure ulcer prevalence survey. Advances in Wound Care, 10:18-26, 1997.

E.L.A. Blezer, K. Nicolay, R. Goldschmeding, G.H. Jansen, H.A. Koomans, T.J. Rabelink and J.A. Joles. Early-onset but not late-onset endothelin-a-receptor blockade can modulate hypertension, cerebral edema, and proteinuria in stroke-prone hypertensive rats. Hypertension, 33:137-144, 1999.

M.R. Bliss. Acute pressure area care: Sir James Paget's legacy. Lancet, 339:221-223, 1992.

M.R. Bliss. Aetiology of pressure sores. Reviews in Clinical Gerontology, 3:379-397, 1993.

E.M.H. Bosboom, C.V.C. Bouten, C.W.J. Oomens, H.W.M. van Straaten, F.PT. Baaijens and $\mathrm{H}$. Kuipers. Quantification and localisation of damage in rat muscles after controlled loading; a new approach to study the aetiology of pressure sores. Medical Engineering and Physics, 23:195-2000, 2001a.

E.M.H. Bosboom, M.K.C. Hesselink, C.W.J. Oomens, C.V.C. Bouten, M. Drost and F.P.T. Baaijens. Passive transverse mechanical properties of skeletal muscle under in vivo compression. Journal of Biomechanics, 34:1365-1368, 2001b.

G.J.J.W. Bours, R.J.G. Halfens, M. Lubbers and J.R.E. Haalboom. The development of a national registration form to measure the prevalence of pressure ulcers in the Netherlands. Ostomy/Wound Management, 45:28-40, 1999.

C.V.C. Bouten, E.M.H. Bosboom and C.W.J. Oomens. The aetiology of pressure sores: A tissue and cell mechanics approach. In L.H.V. van de Woude, M.T.E. Hopman and C.V. van Kemenade, editors, Biomedical Aspects of Manual Wheelchair Propulsion: The state of the art II, pages 52-62. IOP Press Amsterdam, 1999.

C.V.C. Bouten, M.M. Knight, D.A. Lee and D.L. Bader. Compressive deformation and 
damage of muscle cell subpopulations in a model system. Annals of Biomedical Engineering, 29:153-163, 2001.

C.V.C. Bouten, J.M. Stijnen, C.W.J. Oomens, H. Kuipers and J.D. Janssen. Interstitial fluid pressure measurement during compressive loading of the rat tibialis anterior muscle. Bioengineering conference ASME, 35:491-492, 1997.

R.G.M. Breuls, B.G. Sengers, C.W.J. Oomens, C.V.C. Bouten and F.P.T. Baaijens. Predicting local cell deformations in engineered tissue constructs: A multilevel finite element approach. Journal of Biomechanical Engineering, submitted, 2001.

H.E. Cabaud, A. Chatty, V. Gildengorin and R.J. Feltman. Exercise effect on the strength of the rat anterior cruciate ligament. The American Journal of Sports Medicine, 8:79-86, 1980.

R.S. Candadai and N.P. Reddy. Stress distribution in a physical buttock model: Effect of simulated bone geometry. Journal of Biomechanics, 25:1403-1411, 1992.

C.C. Chow and E.I. Odell. Deformations and stresses in soft body tissues of a sitting person. Journal of Biomechanical Engineering, 100:79-86, 1978.

P.A. Dabnichki, A.D. Crocombe and S.C. Hughes. Deformation and stress analysis of supported buttock contact. Proceedings of the Institution of Mechanical Engineers. Part H, Journal of Engineering in Medicine, 208:9-17, 1994.

R.K. Daniel, D.L. Priest and D.C. Wheatley. Etiologic factors in pressure sores: An experimental model. Archives of Physical Medicine and Rehabilitation, 62:492-498, 1981.

R.A. de Graaf, A. van Kranenburg and K. Nicolay. In vivo ${ }^{31}$ P-NMR diffusion spectroscopy of ATP and phosphocreatine in rat skeletal muscle. Biophysical Journal, 78:1657-1664, 2000.

S.M. Dinsdale. Decubitus ulcers: Role of pressure and friction in causation. Archives of Physical Medicine and Rehabilitation, 55:147-152, 1974.

K.T. Dodd and D.R. Gross. Three-dimensional tissue deformation in subcutaneous tissues overlying bony prominences may help to explain external load transfer to the interstitium. Journal of Biomechanics, 24:11-19, 1991.

J.L. Fleckenstein. Skeletal muscle evaluated by MRI. In D.M. Grant and R.K. Harris, editors, Encyclopedia of Nuclear Magnetic Resonance, pages 4430-4436. Chichester, Wiley, 1996.

A.W.J. Gielen, C.W.J. Oomens, PH.M. Bovendeerd, T. Arts and J.D. Janssen. A finite element approach for skeletal muscle using a distributed moment model of contraction. Computer Methods in Biomechanics and Biomedical Engineering, 3:231244, 2000. 
B. Goldstein and J. Sanders. Skin response to repetitive mechanical stress: A new experimental model in pig. Archives of Physical Medicine and Rehabilitation, 79:265$272,1998$.

R.H.M. Goossens, R. Zegers, G.A. Hoek van Dijke and C.J. Snijders. Influence of shear on oxygen tension. Clinical Physiology, 14:111-118, 1994.

D. Hawkins and M. Bey. Muscle and tendon force-length properties and their interactions in vivo. Journal of Biomechanics, 30:63-70, 1997.

Health Council of the Netherlands. Pressure Ulcers. The Hague: Health Council of the Netherlands, 1999. Publication no. 1999/23.

J.Y Hencey, M. Vermess, H.H. van Geertruyden, J.E. Binard and S. Manchepalli. Magnetic resonance imaging examinations of gluteal decubitus ulcers in spinal cord injury patients. Journal of Spinal Cord Medicine, 19:5-8, 1996.

M.K.C. Hesselink, H. Kuipers, P. Geurten and H. van Straaten. Structural muscle damage and muscle strength after incremental number of isometric and forced lengthening contractions. Journal of Muscle Research and Cell Motility, 17:335-341, 1996.

T. Husain. An experimental study of some pressure effects on tissues, with reference to the bed-sore problem. The Journal of Pathology and Bacteriology, 66:347-358, 1953.

M. Kojic, S. Mijailovic and N. Zdravkovic. Modelling of muscle behaviour by the finite element method using Hill's three-element model. International Journal for Numerical Methods in Engineering, 43:941-953, 1998.

J.Y. Kokate, K.J. Leland, A.M. Held, G.L. Hansen, G.L. Kveen, B.A. Johnson, M.S. Wilke, E.M. Sparrow and P.A. Iaizzo. Temperature-modulated pressure ulcers: A porcine model. Archives of Physical Medicine and Rehabilitation, 76:666-673, 1995.

M. Kosiak. Etiology of decubitus ulcers. Archives of Physical Medicine and Rehabilitation, 42:19-29, 1961.

T.A. Krouskop. A synthesis of the factors that contribute to pressure sore formation. Medical Hypotheses, 11:255-267, 1983.

A.S. Landsman, D.F. Meaney, R.S. Cargill, E.J. Macarak and L.E. Thibault. A theory on the mechanical etiology of diabetic foot ulcerations. Journal of the American Podiatric Medical Association, 85:519-527, 1995.

M. Maenhout, M.K.C. Hesselink, E. Blezer, A. van der Toorn, K. Nicolay, C.W.J. Oomens and M. Drost. Acquisition of the three-dimensional displacement field of the rats TA muscle during isometric contraction based on transverse and longitudinal tagged images. Magnetic Resonance in Medicine, submitted, 2001. 
A.F.T. Mak, L. Huang and Q. Wang. A biphasic poroelastic analysis of the flow dependent subcutaneous tissue pressure and compaction due to epidermal loadings: issues in pressure sore. Journal of Biomechanical Engineering, 116:421429, 1994.

MARC Analysis Research Corporation. MARC Volume A: Theory and User Information, Volume B: Element Library, Volume C: Program Input, Version K7. 1997.

J.A.C. Martins, E.B. Pires, R. Salvado and P.B. Dinis. A numerical model of passive and active behavior of skeletal muscles. Computer Methods in Applied Mechanics and Engineering, 151:419-433, 1998.

J.H. Meijer, G.L. Schut, M.W. Ribbe, H.G. Goovaerts, R. Nieuwenhuys, J.P.H. Reulen and $H$. Schneider. Method for the measurement of susceptibility to decubitus ulcer formation. Medical and Biological Engineering and Computing, 27:502-506, 1989.

B.S. Myers, C.T. Woolley, T.L. Slotter, W.E. Garrett and T.M. Best. The influence of strain rate on the passive and stimulated engineering stress-large strain behavior of the rabbit tibialis anterior muscle. Journal of Biomechanical Engineering, 120:126$132,1998$.

G.T. Nola and L.M. Vistnes. Differential response of skin and muscle in the experimental production of pressure sores. Plastic and Reconstructive Surgery, 66:728-733, 1980.

K. O'Dea. The prevalence of pressure damage in acute care hospital patients in the UK. Journal of Wound Care, 8:192-194, 1999.

R.W. Ogden. Elastic deformations in rubberlike solids. In H.G. Hopkins and M.J. Sewell, editors, Mechanics of Solids, The Rodney Hill 60th anniversary volume, pages 499-537. Pergamon Press, 1982.

C.W.J. Oomens. A mixture approach to the mechanics of skin and subcutis: A contribution to pressure sore research. Ph.D. thesis, University of Twente, 1985.

C.W.J. Oomens, O.F.J.T. Bressers, E.M.H. Bosboom, C.V.C. Bouten and D.L. Bader. Deformation analysis of a supported buttock contact. Journal of Rehabilitation Research and Development, submitted, 2001.

C.W.J. Oomens, M.R. van Ratingen, J.D. Janssen, J.J. Kok and M.A.N. Hendricks. A numerical-experimental method for a mechanical characterisation of biological materials. Journal of Biomechanics, 26:617-621, 1993.

S.M. Peirce, T.C. Skalak and G.T. Rodeheaver. Ischemia-reperfusion injury in chronic pressure ulcer formation: A skin model in the rat. Wound Repair and Regeneration, 8:68-76, 2000.

N.P. Reddy. Effects of mechanical stresses on lymph and interstitial fluid flows. In D.L. Bader, editor, Pressure sores: Clinical practice and scientific approach, pages 203-220. The Macmillan Press Ltd, 1990. 
S.I. Reger, T.F. McGovern and K.C. Chung. Biomechanics of tissue distortion and stiffness by magnetic resonance imaging. In D.L. Bader, editor, Pressure sores: Clinical practice and scientific approach, pages 177-190. The Macmillan Press Ltd, 1990.

J.B. Reswick and J. Rogers. Experience at Rancho Los Amigos hospital with devices and techniques to prevent pressure sores. In R.M. Kenedi, J.M. Cowden and J.T. Scales, editors, Bed sore biomechanics, pages 301-310. The Macmillan Press Ltd, 1976.

C.M. Ruan, E. Escobedo, S. Harrison and B. Goldstein. Magnetic resonance imaging of nonhealing pressure ulcers and myocutaneous flaps. Archives of Physical Medicine and Rehabilitation, 79:1080-1088, 1998.

T.J. Ryan. Cellular responses to tissue distortion. In D.L. Bader, editor, Pressure sores: clinical practice and scientific approach, pages 141-152. The Macmillan Press Ltd, 1990.

G. Saab, R.T. Thompson and G.D. Marsh. Effects of exercise on muscle transverse relaxation determined by $\mathrm{MR}$ imaging and in vivo relaxometry. Journal of Applied Physiology, 88:226-233, 2000.

R. Salcido, J.C. Donofrio, S.B. Fisher, E.K. LeGrand, K. Dickey, J.M. Carney, R. Schosser and R. Liang. Histopathology of pressure ulcers as a result of sequential computer-controlled pressure sessions in a fuzzy rat model. Advances in Wound Care, 7:23-40, 1994.

W.O. Seiler and H.B. Stähelin. Skin oxygen tension as a function of imposed skin pressure: Implication for decubitus ulcer formation. Journal of American Geriatric Society, 27:298-301, 1979.

V. Straub, K.M. Donahue, V. Allamand, R.L. Davisson, Y.R. Kim and K.P. Campbell. Contrast agent-enhanced magnetic resonance imaging of skeletal muscle damage in animal models of muscular dystrophy. Magnetic Resonance in Medicine, 44:655659, 2000.

A. Thoroddsen. Pressure sore prevalence: A national survey. Journal Clinical Nursing, 8:170-179, 1999.

B.A. Todd and J.G. Thacker. Three-dimensional computer model of human buttocks, in vivo. Journal Rehabilitation Research and Development, 31:111-119, 1994.

A.J. van der Kleij, D.J. Bakker, M. Lubbers and C.P. Henny. Skeletal muscle pO2 in anaerobic soft tissue infections during hyperbaric oxygen therapy. Advances in Experimental Medicine and Biology, 317:125-129, 1992.

C.C. van Donkelaar, P.J.B. Willems, A.M.M. Muijtjens and M.R. Drost. Skeletal muscle transverse strain during isometric contraction at different lengths. Journal of Biomechanics, 32:755-762, 1999. 
W.J. Vankan, J.M. Huyghe, C.C. van Donkelaar, M.R. Drost, J.D. Janssen and A. Huson. Mechanical blood-tissue interaction in contracting muscles: A model study. Journal of Biomechanics, 31:401-409, 1998.

W. Wiig, R.K. Reed and K. Aukland. Micropuncture measurement of interstitial fluid pressure in rat subcutis and skeletal muscle: Comparison to wick-in-needle technique. Microvascular Research, 21:308-319, 1981. 


\section{Samenvatting}

Drukwonden zijn lokale degeneraties van huid en/of de onderliggende weefsels, zoals subcutaan vetweefsel of spierweefsel. Ze worden veroorzaakt door een langdurige mechanische belasting die extern, op de huid, wordt uitgeoefend en kunnen bijvoorbeeld ontstaan bij personen die bedlegerig zijn, in een rolstoel zitten of een prothese dragen. Drukwonden zijn belastend voor de patiënt en kunnen vooral in de beginstadia erg pijnlijk zijn. De prevalentie van drukwonden is hoog; ongeveer $10 \%$ van de patiënten in een ziekenhuis heeft drukwonden. Een adequate preventie is moeilijk, omdat fundamentele kennis over de ontstaansmechanismen van drukwonden ontbreekt. Het is namelijk niet bekend hoe de externe belasting op de huid resulteert in lokale spanningen en rekken in de weefsels en hoe deze lokale belastingen uiteindelijk tot weefselschade kunnen leiden. Bovendien richt preventie zich met name op de huid, terwijl spierweefsel gevoeliger is voor mechanische belastingen en de meest ernstige drukwonden vaak in de spier ontstaan.

Het doel van deze studie is inzicht te krijgen in de relatie tussen langdurige mechanische belasting en lokale spierschade. Hiervoor zijn een diermodel en een eindige elementen model ontwikkeld. Het diermodel tracht een gecontroleerde externe belasting te relateren aan de lokatie en hoeveelheid spierschade. Het eindige elementen model wordt gebruikt om de lokale mechanische toestand in de spier te bepalen die ontstaat als gevolg van de externe belasting. Het vergelijken van de lokale spierschade en de lokale mechanische toestand kan vervolgens de lokale mechanische grootheden opleveren, die kritisch zijn voor het ontstaan van schade. Dit leidt tot een betere voorspelling van de consequenties van een externe belasting voor het ontstaan van weefselschade.

Eerder onderzoek naar de ontstaansmechanismen van drukwonden bleef beperkt tot de vraag of er al dan niet schade ontstond. Om externe belasting te kunnen relateren aan lokale spierschade werd daarom gebruik gemaakt van een nieuw diermodel en schadedetectie technieken. Bij elf mannelijke Brown Norway ratten werd de tibialis anterior spier samen met de huid gedurende enkele uren samengedrukt tussen een stempel en de tibia. Vierentwintig uur na de belasting werd de spier uitgenomen 
en onderzocht op de aanwezigheid van schade. Schade is hierbij gedefinieerd als een verlies aan dwarsstreping van de spiervezels en de infiltratie van mononucleaire cellen. De hoeveelheid en de lokatie van de schade werd bepaald met behulp van een semi-automatisch beeldverwerkingsprogramma, waarmee een drie dimensionale reconstructie gemaakt kon worden van de spier en het schadegebied. Wanneer het belastingsprotocol leidde tot schade, was de schade gelokaliseerd in een zone nabij de plaats van indrukking en strekte deze zich uit van de oppervlakkige tot de diepe spierlagen.

De hierboven beschreven histologische schadedetectie technieken hebben als nadeel dat zij erg arbeidsintensief zijn, waardoor het aantal uit te voeren experimenten beperkt is. Bovendien wordt voor histologische technieken het weefsel uitgenomen, waardoor vervolgstudies of klinische toepassingen niet mogelijk zijn. Daarom is, naast histologie, T2 gewogen hoge resolutie MRI gebruikt om het belaste spierweefsel te bestuderen. Daartoe werden de eerder beschreven dierexperimenten herhaald, met dien verstande dat nu 24 uur na afloop van het belastingsprotocol in vivo MR beelden gemaakt werden van zowel de belaste als de contralaterale achterpoot. Wederom werd de tibialis anterior spier uitgenomen en verwerkt voor histologie, zodat de MRI resultaten geïnterpreteerd konden worden. Uit de resultaten bleek dat de signaalintensiteit in de MR beelden hoger was in het belaste spierweefsel dan in het onbelaste spierweefsel. Het gebied met een hogere signaalintensiteit viel samen met de lokatie van schade bepaald met histologie. Bovendien kwam het oppervlak met een hogere signaalintensiteit in de MR beelden overeen met het schadeoppervlak bepaald uit de histologie. MRI is dus een veelbelovend alternatief voor histologie in onderzoek naar de ontstaansmechanismen van drukwonden.

Om de lokale spanningen en rekken in de spier als gevolg van de externe belasting te bepalen is een eindige elementen model ontwikkeld van de tibialis anterior spier en de omliggende weefsels. Dit model maakt gebruik van constitutieve vergelijkingen om het passieve gedrag van spierweefsel te beschrijven. Omdat er geen gegevens beschikbaar waren over de passieve dwarseigenschappen van spierweefsel zijn compressie-experimenten uitgevoerd met als doel deze eigenschappen te bepalen. Tijdens deze compressie-experimenten werd speciale aandacht besteed aan het in leven houden van de spier. Het experimentele protocol resulteerde in een inhomogene spannings- en rekverdeling in de spier. Om de spanningsen rekverdeling te bepalen werd een vlakspanningsmodel gebruikt. In het vlakspanningsmodel werd het passieve gedrag van het spierweefsel beschreven met een incompressibel viscoelastisch Ogden model. De materiaalparameters van het Ogden model werden bepaald door de resultaten van het model op de experimentele data te fitten (numeriek-experimentele methode). 
Het eindige elementen model kent echter nog een aantal onzekerheden, zoals de isotropie in de materiaalwet voor de spier, de dwarseigenschappen van huid, de richting waarin de belasting is aangebracht en de randvoorwaarden die gelden bij het vlak tussen spier en het membrana interossea, een stijf membraan van collageen tussen de tibia en de fibula. Om het effect van de gemaakte keuzes te bepalen werden extra simulaties uitgevoerd. Het grootste deel van deze parametervariaties had weinig invloed op de resultaten $(<8 \%)$. Het veranderen van de randvoorwaarden op het vlak tussen spier en membrana interossea had echter erg veel effect. In een toekomstige studie zal dus de vervorming in dit vlak bepaald moeten worden, bijvoorbeeld met MRI-tagging.

Door de resultaten van het diermodel en het eindige elementen model te vergelijken werd de hypothese getoetst dat langdurige celvervorming leidt tot drukwonden. Als er inderdaad een eenduidige relatie bestaat tussen celvervorming en spierschade, dan moet de verdeling van maximale afschuifrekken bepaald in de eindige elementen berekeningen gerelateerd zijn aan de hoeveelheid en lokatie van spierschade bepaald in de dierexperimenten. De vergelijking resulteerde in een gedeeltelijke overlap tussen de afschuifrekverdeling en het schadegebied. Desondanks waren de resultaten niet overtuigend genoeg om te concluderen dat celvervorming de voornaamste oorzaak is voor het ontstaan van spierschade. Verder onderzoek zal moeten verduidelijken wat tijdens het ontstaan van drukwonden de relatieve bijdrage is van celvervorming en andere factoren die leiden tot weefselschade, zoals ischemie en interstitiële veranderingen.

De vergelijking van dierexperimenten en eindige elementen berekeningen werd bemoeilijkt door de grote variatie in gevoeligheid voor spierschade die gevonden werd voor de verschillende proefdieren. In de klinische praktijk worden verschillen in gevoeligheid van patiënten vaak verklaard aan de hand van onderliggende pathologie of verschillen in risicofactoren, zoals leeftijd, mobiliteit en voedingsstatus. Deze verklaringen zijn hier niet van toepassing, omdat de proefdiereigenschappen, de experimentele omstandigheden en de belastingscondities identiek waren. Meer onderzoek naar de grote variatie in gevoeligheid is nodig, omdat het aantal proefdieren beperkt was en slechts één belastingsprotocol werd gebruikt. Echter, als verschillen in gevoeligheid inderdaad niet alleen verklaard kunnen worden uit onderliggende pathologie of al bekende risicofactoren, dan zal dit grote consequenties hebben voor de preventie van drukwonden.

Deze studie heeft aangetoond dat vervorming kan leiden tot aanzienlijke schade in spierweefsel, maar de onderliggende mechanismen zijn nog niet duidelijk geworden. De hier beschreven fundamentele aanpak, waarbij gebruik gemaakt wordt van experimentele en numerieke modellen, stelt ons echter wel in staat de etiologie van drukwonden volledig in kaart te brengen. 


\section{Dankwoord}

Graag wil ik iedereen bedanken die een bijdrage geleverd heeft aan dit proefschrift.

Ik ben vooral veel dank verschuldigd aan mijn copromotoren, Carlijn Bouten en Cees Oomens, voor hun begeleiding, enthousiasme en betrokkenheid. Ook mijn promotoren, Frank Baaijens en Harm Kuipers, en oud-promotor, Jan Janssen, wil ik bedanken voor de begeleiding en voor het mogelijk maken van dit onderzoek.

Roel Breuls en Sjaak Thomassen hebben hun afstudeerwerk uitgevoerd binnen dit project en daarmee veel invloed gehad op de inhoud van dit proefschrift. Nicole van Overveld en Michiel Roersma waren als stagiair betrokken bij het onderzoek. Ik wil jullie allen bedanken voor jullie bijdrage. Daarnaast hebben ook Dan Bader, Maarten Drost, Matthijs Hesselink, Klaas Nicolay en Hennie van Straaten inhoudelijk aan dit proefschrift bijgedragen. Bedankt voor de stimulerende discussies.

De experimenten in Maastricht waren niet gelukt zonder de hulp van Carlijn Bouten, Matthijs Hesselink en Paul Willems, terwijl ik met al mijn vragen over histologie terecht kon bij Paul van Dijk, Johan Hekking en Els Terwindt. Bij de MRI experimenten in Utrecht hebben met name Erwin Blezer, Klaas Nicolay, Boudewijn van der Sanden, Wouter Veldhuis en Gerard van Vliet geholpen. Daarnaast zijn allerlei kleine klusjes rond de experimenten opgeknapt door Rob van de Berg, Sjef Garenfeld en Toon van Gils. Dank voor jullie hulp.

René, ik ben veel wijzer geworden van onze discussies. Bedankt voor al je commentaar op mijn artikelen, voor je hulp bij het maken van presentaties en de omslag van dit proefschrift en voor nog veel meer.

Tenslotte wil ik mijn ouders bedanken voor hun onvoorwaardelijke steun en vertrouwen. En natuurlijk Antonie, jou wil ik het meest bedanken van iedereen. Zonder jouw steun was dit niet gelukt. 
72 Dankwoord 


\section{Curriculum Vitae}

Mariëlle Bosboom werd geboren op 9 Maart 1973 in Bunnik. In 1991 behaalde zij haar VWO diploma aan het Stedelijk Gymnasium te Utrecht. Aansluitend studeerde zij aan de Technische Universiteit Eindhoven. Nadat zij haar propedeuse Werktuigbouwkunde behaald had, volgde zij de postpropedeutische opleiding Werktuigkundige Medische Technologie. In december 1996 studeerde zij af. Haar afstudeerproject betrof een mengselmodel van zachte weefsels voor onderzoek naar het ontstaan van drukwonden. Omdat het onderzoek naar drukwonden haar interesse had gewekt, bleef zij als assistent in opleiding binnen deze onderzoekslijn werken. Dit proefschrift is het resultaat van haar promotie-onderzoek, dat viel binnen het samenwerkingsverband van de Technische Universiteit Eindhoven en de Universiteit Maastricht. Sinds 1 mei 2001 is zij werkzaam als wetenschappelijk medewerker onderzoek en onderwijs bij de faculteit Biomedische Technologie van de Technische Universiteit Eindhoven. 
74 Curriculum Vitae 